\title{
Relative influence of dietary protein and energy contents on lysine requirements and voluntary feed intake of rainbow trout fry
}

\author{
Mélusine Van Larebeke*, Guillaume Dockx, Yvan Larondelle and Xavier Rollin* \\ Institut des Sciences de la Vie, Université catholique de Louvain, Place Croix du Sud 2/L7.05.08, \\ 1348 Louvain-la-Neuve, Belgium \\ (Submitted 7 January 2017 - Final revision received 29 October 2017 - Accepted 30 October 2017-First published online 11 December 2017)
}

\section{Abstract}

The effect of dietary digestible protein (DP) and/or digestible energy (DE) levels on lysine (Lys) requirements, Lys utilisation efficiency and voluntary feed intake (VFI) were studied in rainbow trout fry when Lys was the first limiting indispensable amino acid or in excess in the diet. Two trials were conducted at $11 \cdot 6^{\circ} \mathrm{C}$ with eighty-one experimental diets, containing $280 \mathrm{~g} \mathrm{DP} / \mathrm{kg}$ DM (low protein (LP), trial 1), $600 \mathrm{~g}$ DP/kg DM (high protein (HP), trial 1) or $440 \mathrm{~g} \mathrm{DP} / \mathrm{kg} \mathrm{DM}$ (medium protein (MP), trial 2), $17 \mathrm{MJ} \mathrm{DE} / \mathrm{kg}$ (low energy (LE)), 19.5 MJ DE/kg (medium energy (ME)) or $22 \mathrm{MJ} \mathrm{DE} / \mathrm{kg}$ (high energy (HE)), and nine Lys levels from deeply deficient to large excess (2.3-36 g/kg DM). Each diet was given to apparent satiety to one group of fifty fry (initial body weight $0.85 \mathrm{~g}$ ) for 24 (MP diets, trial 2) or 30 (LP and HP diets, trial 1) feeding days. Based on $\mathrm{N}$ gain data fitted with the broken-line model, the relative Lys requirement was significantly different with the dietary DP level, from $13.3-15.7$ to $22.9-26.5 \mathrm{~g} / \mathrm{kg}$ DM for LP and HP diets, respectively, but did not significantly change with the DE level for a same protein level. The Lys utilisation efficiency for protein growth above maintenance was constant across diets, suggesting no effect of either dietary DE or DP levels. In Lys excess, the VFI was markedly decreased by the DP level but not by the extra DE supply. Our results suggest that the relative Lys need is best expressed in terms of percentage of protein content for optimum fish feed formulation, at least in rainbow trout fry.

\section{Key words: Lysine requirements: Voluntary feed intake: Dietary protein levels: Dietary energy levels: Rainbow trout fry}

The major cost in intensive fish production resides in aquafeeds, and particularly in the dietary protein fraction of carnivorous species feed ${ }^{(1)}$. For years, the main protein source for aquafeeds was fishmeal. It is considered to be the most appropriate for aquatic animals. As its shortage and the increase of its price, plantderived proteins are regarded as a viable alternative ${ }^{(2)}$. Still, most of them are imbalanced or deficient in indispensable (I) amino acids (AA) compared with fishmeal. Because AA requirements are based on a balance, the first limiting IAA determines body protein deposition, and thus body weight gain ${ }^{(1,3)}$.

Commonly, the most limiting IAA in plant-derived proteins are lysine (Lys), methionine and threonine, but Lys is usually the first limiting in these feedstuffs. A dietary Lys deficiency usually depresses growth performance and feed intake ${ }^{(4-6)}$ and has a negative effect on reproduction of several fish species ${ }^{(7)}$. Consequently, a precise knowledge of the Lys requirement is of utmost interest for feed formulation to ensure optimal and rapid growth, cost-effectiveness and minimal environmental impact.

Lys requirement has been determined for several species and wide variations have been reported (12-33 g/ kg DM), even in a same species (13-27 g/kg DM for rainbow trout, Oncorbynchus mykiss $)^{(8)}$. These variations may reflect differences in fish size and cycle stage, feeding regimen, environmental conditions, methodology, experimental model, response criteria, statistical analysis and diet composition ${ }^{(1,8-11)}$. In addition, the relative IAA requirements may be expressed as a proportion of diet content (\%), as a proportion of diet protein content $(\mathrm{g} / 16 \mathrm{~g} \mathrm{~N})$ or per unit of diet digestible energy ( $\mathrm{DE}, \mathrm{g} / \mathrm{MJ}$ ), following the assumption that dietary protein or energy content affects or not the relative requirement ${ }^{(9,12-14)}$. More specifically, the DE content has been assumed to regulate the feed intake with the consequence that a high-energy diet would require a higher AA concentration to compensate for a lower feed intake ${ }^{(13-16)}$. However, several studies are in conflict with the previous results ${ }^{(17,18)}$ and some have suggested that fish eat to reach a targeted protein intake ${ }^{(9,19)}$. In this context, feed composition, particularly in terms of dietary protein and energy contents, is a major factor impacting the robustness of requirement estimates.

The dietary digestible protein (DP) and DE levels are also reported to impact the Lys utilisation efficiency above

Abbreviations: AA, amino acids; CP, crude protein; DE, digestible energy; DP, digestible protein; GE, gross energy; HE, high-energy diets (22 MJ DE/kg DM); $\mathrm{HP}$, high-protein diets (600 g DP/kg DM); IAA, indispensable AA; LE, low-energy diets (17 MJ DE/kg DM); LP, low-protein diets (280 g DP/kg DM); Lys, lysine; MBW, metabolic body weight; ME, medium-energy diets (19.5 MJ DE/kg DM); MP, medium-protein diets (440 g DP/kg DM); NRE, N retention efficiency; VFI, voluntary feed intake.

* Corresponding authors: M. Van Larebeke, email melusine.vanlarebeke@uclouvain.be; X. Rollin, fax +32 10473728, email xavier.rollin@uclouvain.be 
maintenance. Encarnaçao et al. ${ }^{(10)}$ assumed that the energy provided by fatty acids could substitute itself to energy from protein sources, thereby increasing the Lys utilisation efficiency at marginally deficient Lys levels and sparing Lys for protein deposition. On the other side, the level of protein in the diet was found to affect Lys utilisation efficiency ${ }^{(16)}$ or not $^{(20)}$. Clearly, the effect of dietary DP or DE level on the efficiency of IAA utilisation above maintenance remains undetermined in fish.

The objectives of the current study were to determine the effect of both dietary DP and DE levels on the relative and absolute Lys requirements, the efficiency of Lys utilisation for protein deposition and the voluntary feed intake (VFI) in terms of DM, DE and digestible $\mathrm{N}$ intakes in rainbow trout fry. Two trials were conducted to allow comparison between three dietary DP contents and three dietary DE levels, the extreme DP levels being tested in the first trial (LP and HP diets) and the medium DP level (MP diets) in a second trial. In the light of the results, these experiments are expected to help elucidating which expression way is the most appropriate for relative IAA requirements in fish.

\section{Methods}

\section{Experimental diets}

In all, eighty-one semi-purified experimental diets (Table 1) were formulated to contain three DP levels, three DE levels and nine Lys levels (1-9), developing a $3 \times 3 \times 9$ factorial design.
The low-protein (LP, trial 1), the medium-protein (MP, trial 2) and the high-protein (HP, trial 1) diets were formulated to contain 280, 440 and $600 \mathrm{~g}$ DP/kg DM, respectively. The dietary $\mathrm{N}$ sources used are supposed to be totally digestible according to apparent digestiblity of wheat gluten meal, $100 \%$ according to Sugiura et al. ${ }^{(23)}$ and Gaylord et $a l^{(24)}$, and of cystalline AA, $100 \%$ according to Wang et al. ${ }^{(22)}$. The dietary protein content was targeted to be respectively deficient, optimal and in excess, regarding the protein requirement for rainbow trout ${ }^{(25)}$. For the low-energy (LE), medium-energy (ME) and the high-energy (HE) diets, the targeted DE levels were of $17,19.5$ and $22 \mathrm{MJ} / \mathrm{kg}$ $\mathrm{DM}$, respectively. The lowest energy content met the energy requirement of rainbow trout ${ }^{(8)}$. Therefore, we provided extra DE in the ME and HE diets, as compared with the trout energy needs. For diets LP1 to LP9, regardless of the energy level, the targeted Lys levels were of $2 \cdot 26,5 \cdot 38,8 \cdot 51,11 \cdot 63$, 14.75, 17.88, $21,28.5$ and $36 \mathrm{~g} / \mathrm{kg}$ DM. For diets MP1 to MP9, the targeted Lys levels were of $3 \cdot 67,7 \cdot 71,11 \cdot 75,15 \cdot 79,19 \cdot 83,23 \cdot 87,27 \cdot 92,31 \cdot 96$ and $36 \mathrm{~g} / \mathrm{kg}$ DM. For diets HP1 to HP9, they were of $5 \cdot 07$, $7 \cdot 73,10 \cdot 38,13 \cdot 04,15 \cdot 69,18 \cdot 35,21,28.5$ and $36 \mathrm{~g} / \mathrm{kg}$ DM. The targeted Lys levels were provided from deeply deficient levels to large excess, $50 \%$ above the recommendations reported for rainbow trout by the National Research Council ${ }^{(8)}$.

To minimise uncertainty on diet composition and in particular in dietary Lys contents, formulation was based on procedure as previously described ${ }^{(9)}$. A total of twelve 'mother' diets were produced (LPLE1, LPLE9, LPME1, LPME9, LPHE1,

Table 1. Composition of the experimental diets used for determining the influence of dietary digestible protein (DP) and dietary digestible energy (DE) levels on lysine (Lys) requirements, Lys utilisation efficiency and voluntary feed intake in rainbow trout fry fed nine dietary Lys levels from deeply deficient to large excess

\begin{tabular}{|c|c|c|c|c|c|c|c|c|c|}
\hline Diets & LPLE1-9 & LPME1-9 & LPHE1-9 & MPLE1-9 & MPME1-9 & MPHE1-9 & HPLE1-9 & HPME1-9 & HPHE1-9 \\
\hline \multicolumn{10}{|l|}{ Components (g/kg DM) } \\
\hline Wheat gluten meal ${ }^{*}$ & $166 \cdot 00$ & $166 \cdot 00$ & $166 \cdot 00$ & $269 \cdot 35$ & $269 \cdot 35$ & $269 \cdot 35$ & $372 \cdot 70$ & $372 \cdot 70$ & $372 \cdot 70$ \\
\hline L-Amino acid mixture $†$ & $117 \cdot 31$ & $117 \cdot 31$ & $117 \cdot 31$ & 184.87 & 184.87 & $184 \cdot 87$ & 252.44 & 252.44 & 252.44 \\
\hline Modified starch $\ddagger$ & $386 \cdot 70$ & $319 \cdot 70$ & $246 \cdot 70$ & $200 \cdot 78$ & $197 \cdot 28$ & $175 \cdot 78$ & 14.86 & 74.86 & $104 \cdot 86$ \\
\hline Glucose§ & 80 & 60 & 40 & 40 & 30 & 20 & 0 & 0 & 0 \\
\hline Sucrose§ & 80 & 60 & 40 & 40 & 30 & 20 & 0 & 0 & 0 \\
\hline Cellulose§ & 0 & 0 & 0 & 95 & 43 & 0 & 190 & 85 & 0 \\
\hline Cod liver oilll & 40 & 147 & 260 & 40 & 116 & 200 & 40 & 85 & 140 \\
\hline Soya lecithin & 30 & 30 & 30 & 30 & 30 & 30 & 30 & 30 & 30 \\
\hline Vitamin $\operatorname{mix}^{\star *}$ & 10 & 10 & 10 & 10 & 10 & 10 & 10 & 10 & 10 \\
\hline Mineral mix †† & 40 & 40 & 40 & 40 & 40 & 40 & 40 & 40 & 40 \\
\hline Agar§ & 10 & 10 & 10 & 10 & 10 & 10 & 10 & 10 & 10 \\
\hline Carboxymethylcellulose§ & 40 & 40 & 40 & 40 & 40 & 40 & 40 & 40 & 40 \\
\hline \multicolumn{10}{|l|}{ Proximate composition } \\
\hline DM (g/kg diet) & 853.90 & $875 \cdot 75$ & 891.49 & 924.43 & $940 \cdot 20$ & $943 \cdot 20$ & 935.79 & $936 \cdot 31$ & 929.62 \\
\hline Ash (g/kg DM) & $39 \cdot 21$ & 39.64 & $37 \cdot 76$ & $39 \cdot 60$ & $39 \cdot 13$ & $38 \cdot 41$ & 39.99 & 38.61 & 39.06 \\
\hline Crude protein (g/kg DM) & $272 \cdot 66$ & $275 \cdot 87$ & $278 \cdot 18$ & $430 \cdot 82$ & 430.05 & $432 \cdot 62$ & 588.99 & $584 \cdot 24$ & 587.05 \\
\hline Crude lipid (g/kg DM) & $79 \cdot 41$ & 188.51 & $299 \cdot 30$ & 83.93 & 161.68 & 244.97 & 88.44 & $134 \cdot 84$ & $190 \cdot 63$ \\
\hline Gross energy (kJ/g DM) & $20 \cdot 24$ & $22 \cdot 18$ & $25 \cdot 06$ & $20 \cdot 53$ & $22 \cdot 67$ & 24.43 & $20 \cdot 82$ & $23 \cdot 17$ & 23.80 \\
\hline
\end{tabular}

LP, low-protein diets (280 g DP/kg DM); MP, medium-protein diets (440 g DP/kg DM); HP, high-protein diets (600 g DP/kg DM); LE, low-energy diets (17 MJ DE/kg DM); ME, mediumenergy diets (19.5 MJ DE/kg DM); HE, high-energy diets (22 MJ DE/kg DM).

* Dumoulin S.A.

† For composition, see Table 2.

$\ddagger$ Roquette.

§ Sigma-Aldrich.

II Certa; SA Aca Pharma.

II MannaVital.

${ }_{* \star}^{*}$ Supplied the following (to provide $\mathrm{g} / \mathrm{kg}$ premix; according to Rollin et al. $\left.{ }^{(21)}\right)$ : retinyl acetate $(450 \mathrm{mg}$ retinol equivalents/g), $0.67 ;$ cholecalciferol (100 mg cholecalciferol equivalents/g), 0.1 ; tocopheryl acetate $(1000 \mathrm{mg}$ DL-a-tocopherol equivalents $/ \mathrm{g})$, 34.2; menadione, 2.2; ascorbic acid, 120; thiamin, 5.6; riboflavin, 12; pyridoxine, 4.5; calcium panthothenate, 14.1; p-aminobenzoic acid, 40; cyanocobalamin, 0.03; niacin, 30; biotin, 0.1; choline chloride, 350; folic acid, 1.5; inositol, 50; canthaxantin, 10; butylated hydroxyanisole, 1.5; butylated hydroxytoluene, 1.5; cellulose, 322.09.

†† Supplied the following (to provide g/kg premix; according to Rollin et al. ${ }^{(22)}$ ): $\mathrm{CaHPO}_{4} \cdot 2 \mathrm{H}_{2} \mathrm{O}, 295 \cdot 5 ; \mathrm{Ca}\left(\mathrm{H}_{2} \mathrm{PO}_{4}\right)_{2} . \mathrm{H}_{2} \mathrm{O}, 217 ; \mathrm{NaHCO}_{3}, 94.5 ; \mathrm{Na}_{2} \mathrm{SeO}{ }_{3}, 0.00723 ; \mathrm{KCl}, 100 ; \mathrm{NaCl}$, $172.4 ; \mathrm{KI}, 0.2 ; \mathrm{MgCl}_{2}, 63.7 ; \mathrm{MgSO}_{4} .7 \mathrm{H}_{2} \mathrm{O}, 70 \cdot 24 ; \mathrm{MnSO}_{4} \cdot \mathrm{H}_{2} \mathrm{O}, 1.51 ; \mathrm{FeSO}_{4} .7 \mathrm{H}_{2} \mathrm{O}, 12 \cdot 41 ; \mathrm{CuSO}_{4} \cdot 5 \mathrm{H}_{2} \mathrm{O}, 0.4 ; \mathrm{ZnSO}_{4} .7 \mathrm{H}_{2} \mathrm{O}, 10$. 
LPHE9, HPLE1, HPLE9, HPME1, HPME9, HPHE1 and HPHE9). The MP1 and MP9 diets used in trial 2 were made by mixing on a DM basis the LP1 and the HP1 and the LP9 and HP9 diets used in trial 1, respectively, according to the dietary energy level. For a specific dietary protein and energy content, the diet with the highest Lys concentration (diet 9, at $36 \mathrm{~g}$ Lys/kg DM) was diluted with the diet with the lowest Lys concentration (diet 1, at 2.26, 3.67 and 5.07 $\mathrm{g}$ Lys/kg DM for LP1, MP1 and HP1 diets, respectively) to produce seven other diets with intermediate levels of Lys (diets 2-8).

Wheat gluten, deeply deficient in Lys $(1.2 \mathrm{~g} / 16 \mathrm{~g} \mathrm{~N})$, and a mixture of crystalline AA ( $46 \%$ of total $\mathrm{N}$ in all diets) were used as main $\mathrm{N}$ source. The lack of Lys in the wheat gluten-based diets was balanced with increasing doses of L-Lys.HCl. In order to maintain the diets isonitrogenous, the addition of $42 \cdot 17,40 \cdot 41$ and $38.65 \mathrm{~g}$ L-Lys-HCl per $\mathrm{kg}$ mixture was compensed by the deletion of 10.17, 9.92 and 9.68 g L-aspartic acid, 5.95, 6.11 and 5.46 g L-asparagine. $\mathrm{H}_{2} \mathrm{O}, 9.34,8.95$ and $8.56 \mathrm{~g}$ L-alanine, 9.29, 8.9 and $8.51 \mathrm{~g} \mathrm{L-glycine}$ and $5.28,6.22$ and $7.16 \mathrm{~g} \mathrm{L-serine} \mathrm{for} \mathrm{LP,}$ MP and HP diets, respectively (Table 2). Except for Lys, the dietary IAA profile was based on the whole-body AA composition of the rainbow trout, according to Wilson \& Cowey ${ }^{(26)}$.

Energy levels were achieved using different energy sources (Table 1). The DE increase was obtained by substituting cod liver oil for digestible carbohydrates in LP diets and for digestible carbohydrates and cellulose in MP diets. For the HP diets, cellulose was substituted by cod liver oil and modified starch. The accurate experimental determination of the DE contents of our diets is not feasible in trout fry because fish are not large enough to produce a significant quantity of faeces ${ }^{(8,27)}$. Therefore, the DE values were evaluated for each diet from their proximate composition and from the apparent digestibility coefficients of macronutrients ( 1 for crude protein $(\mathrm{CP})^{(8,9)}$, glucose and sucrose $\left.{ }^{(28)}\right)$ or raw materials $(0.95$ for crude lipids ${ }^{(28)}$; 0.85 for modified $\operatorname{starch}^{(28)}$; 0 for cellulose, carboxymethylcellulose and agar-agar). In brief, the DE level

Table 2. Composition of L-amino acid premix ( $\mathrm{g} / \mathrm{kg} \mathrm{DM}$ ) used in the lowprotein (LP), medium-protein (MP) and high-protein (HP) experimental diets

\begin{tabular}{|c|c|c|c|}
\hline Diets & LP1-9 & MP1-9 & HP1-9 \\
\hline $\operatorname{Arg}^{*}$ & $11 \cdot 24$ & $17 \cdot 88$ & 24.52 \\
\hline Hist† & 4.61 & $7 \cdot 32$ & $10 \cdot 02$ \\
\hline$\| e^{*}$ & 5.94 & $9 \cdot 39$ & $12 \cdot 84$ \\
\hline Leu* $^{*}$ & 9.68 & $15 \cdot 28$ & $20 \cdot 87$ \\
\hline Lys.HCl* & $0-42 \cdot 17$ & $0-40 \cdot 41$ & $0-38.65$ \\
\hline Met $^{\star}$ & 5.08 & 8.08 & 11.07 \\
\hline Phe† & $3 \cdot 91$ & $6 \cdot 10$ & 8.29 \\
\hline Tyr* & 3.93 & $6 \cdot 19$ & 8.45 \\
\hline Thr* & 8.58 & $13 \cdot 66$ & $18 \cdot 73$ \\
\hline Trpt & $1 \cdot 13$ & 1.78 & 2.43 \\
\hline Val $^{*}$ & $7 \cdot 41$ & $11 \cdot 74$ & $16 \cdot 07$ \\
\hline Asp* & $10 \cdot 17-0$ & $16 \cdot 22-6 \cdot 30$ & $22 \cdot 27-12 \cdot 59$ \\
\hline Asn. $\mathrm{H}_{2} \mathrm{O}^{*}$ & $11.55-5.60$ & $18 \cdot 83-12 \cdot 72$ & $25 \cdot 30-19 \cdot 84$ \\
\hline $\mathrm{Ala}^{*}$ & $12 \cdot 84-3.50$ & $20 \cdot 46-11.51$ & $28.08-19.52$ \\
\hline Gly* & $14.88-5.59$ & $23.71-14.81$ & $32.54-24.03$ \\
\hline Ser* & $5 \cdot 28-0$ & $8.30-2.08$ & $11 \cdot 32-4 \cdot 16$ \\
\hline Sum & $116 \cdot 23-118 \cdot 38$ & $184.52-185 \cdot 23$ & $252.8-252.08$ \\
\hline
\end{tabular}

* Sigma-Aldrich.

† Ajinomoto USA Inc.
$(\mathrm{MJ} / \mathrm{kg} \quad \mathrm{DM})$ was estimated as: $((\mathrm{CP} \times 23.6 \mathrm{~kJ} / \mathrm{g})+($ crude lipid $\times 0.95 \times 39.5 \mathrm{~kJ} / \mathrm{g})+(($ wheat gluten $\times 0.063 \times 0.85+$ modified starch $\times 0.85+$ glucose + saccharose + soya lecithin $\times 0.09 \times 0.85) \times$ $17 \cdot 2 \mathrm{~kJ} / \mathrm{g}$ )) $/ 1000$. As we mostly used purified or semi-purified ingredients of known proximate and chemical composition ${ }^{(8,29)}$ and as analytical gross energy (GE) values were close to formulations, the DE levels were supposed accurate enough. The experimental diets were produced as previously reported ${ }^{(9,21)}$. In brief, the components were ground in order to make particles less than 100 microns diameter, mixed and homogenised (Kenwood Ltd) before oil addition. In particular, crystalline AA mixtures were coated with $1 \%$ agar, as described by Mambrini \& Kaushik $^{(30)}$, to delay their digestive absorption and optimise their use for protein accretion. After extrusion in a meat grinder (HI 32; Simplex), the experimental diets were freeze-dried, ground, sieved in four fractions $(0.8-1 \mathrm{~mm}, 1-1.25 \mathrm{~mm}, 1.25-1.6 \mathrm{~mm}$ diameter) and stored at $-20^{\circ} \mathrm{C}$ until use. The components and proximate compositions of the diets are shown in Table 1 . The AA composition of the different AA mixtures used is presented in Table 2. The dietary AA composition was analysed for 'mother' diets LPLE1, LPLE9, LPME1, LPME9, LPHE1, LPHE9, HPLE1, HPLE9, HPME1, HPME9, HPHE1 and HPHE9 (Table 3). Analytical dietary AA levels were close to the targeted concentrations (online Supplementary Table S1).

\section{Fish and feeding}

Both experiments performed in this study were approved by the Animal Care and Use Committee of the Universite catholique de Louvain (permit no. 103203) as per the EU legal frameworks relating to the protection of animals used for scientific purposes (Directive 86/609/CEE) and guidelines of Belgian legislation governing the ethical treatment of animals (Decree M.B. 05.01.1994, 14 November 1993). Both experiments were conducted at the 'Plateforme technologique et didactique en biologie aquicole Marcel Huet', in Louvain-laNeuve, which is certified for animal services under the permit no. LA 1220034. The first experiment (trial 1) was conducted with the LP and HP diets and the second experiment (trial 2) complemented the first one with the MP diets.

Rainbow trout (Oncorbynchus mykiss) fry were provided as eggs in our laboratory hatchery. Diploid eyed (embryonic) eggs came from a commercial fish farm (Pisciculture Charles Murgat). After hatching, rainbow trout fry were grown in one single tank and fed with a commercial diet (NUTRA HP; Skretting) until the start of the experiment.

Before each experiment, the fry were submitted to a fasting period of $36 \mathrm{~h}$ and were then distributed into fifty-four (trial 1 ) and twenty-seven (trial 2) indoor 121 aquaria $(0.4 \times$ $0.24 \times 0.2 \mathrm{~m})$. Each aquarium contained fifty fry with an initial body weight of $0.85 \pm 0.06 \mathrm{~g}$. Each test diet was randomly allocated to one aquarium (eighty-one aquaria). Two more aquaria per experiment were filled to provide initial samples. At the start of each experiment, these initial fry were weighed, euthanised with an excess of phenoxyethanol, counted and kept frozen at $-20^{\circ} \mathrm{C}$ until chemical analysis.

Biomass density allowed optimal growth conditions for that specific stage. Aquaria were continuously aerated and supplied 
Table 3. Crude protein ( $\mathrm{g}$ nitrogen $\times 6.25 / \mathrm{kg}$ ) and amino acid (\% of the total amino acids) content analysed in some of the experimental diets used to feed rainbow trout fry*

\begin{tabular}{|c|c|c|c|c|c|c|c|c|c|c|c|c|}
\hline $\begin{array}{l}\text { Diets } \\
(\mathrm{g} \mathrm{N} \times 6 \cdot 25 / \mathrm{kg})\end{array}$ & $\begin{array}{l}\text { LPLE1 } \\
(275 \cdot 12)\end{array}$ & $\begin{array}{l}\text { LPLE9 } \\
(270 \cdot 20)\end{array}$ & $\begin{array}{l}\text { LPME1 } \\
(280 \cdot 00)\end{array}$ & $\begin{array}{l}\text { LPME9 } \\
(271.73)\end{array}$ & $\begin{array}{l}\text { LPHE1 } \\
(284 \cdot 77)\end{array}$ & $\begin{array}{l}\text { LPHE9 } \\
(271.60)\end{array}$ & $\begin{array}{l}\text { HPLE1 } \\
(600 \cdot 77)\end{array}$ & $\begin{array}{l}\text { HPLE9 } \\
(577 \cdot 21)\end{array}$ & $\begin{array}{l}\text { HPME1 } \\
(593.32)\end{array}$ & $\begin{array}{l}\text { HPME9 } \\
(575 \cdot 16)\end{array}$ & $\begin{array}{l}\text { HPHE1 } \\
(596 \cdot 36)\end{array}$ & $\begin{array}{c}\text { HPHE9 } \\
(577 \cdot 74)\end{array}$ \\
\hline \multicolumn{13}{|c|}{ Amino acid content (\%) } \\
\hline Arg & 6.54 & $6 \cdot 88$ & $6 \cdot 27$ & 6.91 & 6.59 & 6.91 & 6.57 & $6 \cdot 71$ & $6 \cdot 40$ & $6 \cdot 41$ & $6 \cdot 33$ & $6 \cdot 61$ \\
\hline His & $2 \cdot 96$ & $3 \cdot 11$ & $2 \cdot 89$ & 2.98 & $2 \cdot 97$ & 3.07 & 2.98 & 3.04 & 2.93 & $2 \cdot 91$ & 2.99 & 2.96 \\
\hline Ile & 4.39 & 4.35 & 4.70 & 4.71 & 4.29 & $4 \cdot 17$ & $4 \cdot 37$ & 4.39 & 4.67 & $5 \cdot 18$ & 4.98 & 4.84 \\
\hline Leu & 8.02 & 7.40 & $9 \cdot 19$ & $9 \cdot 16$ & $8 \cdot 16$ & 7.45 & 7.53 & 7.54 & 7.58 & 7.56 & $7 \cdot 29$ & 7.71 \\
\hline Lys & 0.94 & $15 \cdot 17$ & 0.95 & 14.47 & 0.98 & $15 \cdot 87$ & 0.98 & $6 \cdot 80$ & 1.00 & 6.37 & 0.96 & 6.55 \\
\hline Met & 2.96 & $2 \cdot 85$ & 2.93 & $2 \cdot 85$ & 3.06 & $2 \cdot 74$ & $2 \cdot 86$ & $2 \cdot 78$ & $2 \cdot 90$ & $2 \cdot 89$ & $2 \cdot 81$ & $2 \cdot 82$ \\
\hline Cys & $1 \cdot 12$ & $1 \cdot 19$ & 1.20 & 1.25 & $1 \cdot 19$ & $1 \cdot 31$ & $1 \cdot 14$ & 1.25 & $1 \cdot 24$ & $1 \cdot 23$ & $1 \cdot 19$ & 1.24 \\
\hline Phe & 4.48 & 4.61 & 4.53 & 4.71 & 4.42 & 4.63 & 4.53 & 4.59 & 4.65 & 4.65 & 4.58 & 4.71 \\
\hline Thr & 4.84 & 5.23 & 4.70 & 4.88 & 5.01 & $5 \cdot 22$ & 4.98 & 4.99 & 4.83 & 4.88 & 4.78 & 4.98 \\
\hline Val & 5.24 & 5.54 & 5.44 & $5 \cdot 70$ & 5.35 & 5.52 & $5 \cdot 37$ & 5.35 & 5.35 & 5.74 & 5.47 & 5.55 \\
\hline Asp & $10 \cdot 84$ & 4.71 & 10.51 & 4.49 & 11.30 & 4.67 & 10.67 & 8.07 & 10.63 & 7.97 & 10.65 & 8.06 \\
\hline Glu & $21 \cdot 28$ & $21 \cdot 27$ & 20.94 & 21.04 & 20.44 & 20.93 & 21.56 & $22 \cdot 38$ & 21.59 & $21 \cdot 71$ & 21.62 & 22.02 \\
\hline Ala & $6 \cdot 81$ & 3.11 & 6.51 & 3.02 & 6.93 & $3 \cdot 16$ & 6.81 & 5.23 & 6.62 & $5 \cdot 10$ & 6.63 & 5.22 \\
\hline Gly & 8.02 & 4.35 & $7 \cdot 71$ & $4 . \cdot 23$ & $8 \cdot 16$ & 4.55 & 7.83 & 6.42 & $7 \cdot 80$ & $6 \cdot 31$ & 7.80 & $6 \cdot 45$ \\
\hline Pro & 7.08 & 7.45 & 6.92 & 6.91 & 6.59 & $7 \cdot 12$ & $7 \cdot 10$ & $6 \cdot 86$ & $7 \cdot 12$ & 7.52 & 7.29 & 6.63 \\
\hline Ser & 4.57 & 2.85 & 4.58 & $2 \cdot 76$ & 4.63 & 2.74 & 4.69 & 3.63 & 4.67 & 3.59 & 4.70 & 3.69 \\
\hline
\end{tabular}

* Tyrosine and tryptophan could not be determined with the amino acid analysis method used.

with fresh degassed groundwater by a flow-through system at a rate of $11 / \mathrm{min}$ at $11 \cdot 6 \pm 0.3^{\circ} \mathrm{C}$ under an artificial photoperiod of $8 \mathrm{~h}$ dark $-16 \mathrm{~h}$ light. Water quality and water flow rate were maintained in order to supply sufficient $\mathrm{O}_{2}(>7 \mathrm{mg} / \mathrm{l})$ and to avoid a build-up of $\mathrm{NH}_{3}-\mathrm{N}(<0.1 \mathrm{mg} / \mathrm{l})$ and nitrites-N $(<0.05 \mathrm{mg} / \mathrm{l})$.

The fish were fed manually to apparent satiation for $30 \mathrm{~d}$ (trial 1) or $24 \mathrm{~d}$ (trial 2), $6 \mathrm{~d}$ a week, twice daily (10.00 and 16.00 hours). At the end of the experiment, a tripling of mean initial body weight was expected for fish fed the diets without Lys deficiency. Mortality and the amount of feed distributed to each aquarium were recorded on a daily basis.

At the end of the experimental phase, and after $72 \mathrm{~h}$ of fast, the fish of each aquarium were group weighed, euthanized with an excess of phenoxyethanol, counted and frozen $\left(-20^{\circ} \mathrm{C}\right)$. Initial and final fish whole bodies were freeze-dried (Freeze-drying Christ gamma 1-16 LSC; Osterode am), ground (Grindomix; Rentsch), homogenised and stored at $-20^{\circ} \mathrm{C}$ pending chemical analysis.

\section{Sampling and chemical analyses}

The diets were analysed for DM, crude ash, CP, crude lipid and GE (Table 1). In all, twelve diets were analysed for AA composition (Table 3) in order to verify the targeted dietary IAA concentrations. Initial and final fish whole bodies were analysed for DM, crude ash and CP contents. Because of a lack of material in certain aquaria, whole-body lipid was calculated as follows: Crude lipid $(\% \mathrm{DM})=100-$ crude ash $(\% \mathrm{DM})-\mathrm{CP}(\% \mathrm{DM})$. For six aquaria, fish were analysed for crude lipid to confirm calculations. Furthermore, the GE content was analysed on initial fish and final fish fed on LP and HP diets. GE content of these fish was also calculated as GE $(\mathrm{kJ} / 100 \mathrm{~g} \mathrm{DM})=\mathrm{CP} \times 23 \cdot 6+$ crude lipid $\times$ $39 \cdot 5^{(8)}$. The linear regression between the calculations and analyses of LP and HP fed fry (GE content analysed $=1.0046 \times \mathrm{GE}$ content calculated - 21.35, $R^{2}$ 0.97) was applied to calculated GE content of MP fry to obtain estimates of MP fed fry GE content. All analyses followed the official analytical methods from the Association of Official Analytical Chemists ${ }^{(31)}$ or the Commission
Regulation (EC) No. 152/2009 of 27 January 2009 for AA composition. In brief, DM was measured by drying at $105^{\circ} \mathrm{C}$ for $24 \mathrm{~h}$ and crude ash following incineration at $550^{\circ} \mathrm{C}$ for $16 \mathrm{~h}$. CP was determined after acid digestion with the Kjeldahl method $(\mathrm{N} \times 6 \cdot 25)$, crude lipid with a diethyl ether extraction according to the Soxhlet method and GE with an adiabatic calorimeter (IKA Calorimeter C400 adiabatic; Janke \& Kunkel). Regarding AA composition, the oxidised sample was hydrolysed with hydrochloric acid for $23 \mathrm{~h}$ at $110^{\circ} \mathrm{C}$. Then the AA were separated by ion exchange chromatography and determined through their reaction with ninhydrin followed by a photometric detection. AA analyses were performed under a subcontracting by InVivo Labs, Vannes. All analyses were conducted in duplicate. If the relative difference between the two replicates was over $5 \%$, additional analyses were performed to achieve a relative uncertainty below $5 \%$.

\section{Calculations}

The initial variables were obtained during and after the experimental phase: $D_{\mathrm{i}}$ is the dry diet intake per fish (g DM/fish); $\mathrm{Lys}_{\mathrm{d}}$, $\mathrm{DE}_{\mathrm{d}}$ and $\mathrm{N}_{\mathrm{d}}$ are the dietary Lys $(\mathrm{g} / \mathrm{g} \mathrm{DM}), \mathrm{DE}(\mathrm{kJ} / \mathrm{g} \mathrm{DM})$ and $\mathrm{N}$ contents $(\mathrm{g} / \mathrm{g} \mathrm{DM})$, respectively; $W_{\mathrm{f}}$ and $W_{\mathrm{i}}$ are the mean final and initial fresh body weights $(\mathrm{g} / \mathrm{fish}) ; \Delta \mathrm{t}$ is the number of feeding days; $\mathrm{N}_{\mathrm{f}}$ and $\mathrm{N}_{\mathrm{i}}$ are the average final and initial $\mathrm{N}$ contents of the whole-body fresh fry $(\mathrm{g} / \mathrm{g}) ; n_{\mathrm{f}}$ and $n_{\mathrm{i}}$ are the final and initial numbers of fish per aquarium; $\mathrm{GE}_{\mathrm{f}}$ and $\mathrm{GE}_{\mathrm{i}}$ are the average final and initial GE contents of the whole-body fresh fry $(\mathrm{kJ} / \mathrm{g})$; mean metabolic body weight (MBW) was calculated as $\left(\left(W_{\mathrm{f}} / 1000\right)^{0.75}+\left(W_{\mathrm{i}} / 1000\right)^{0.75}\right) / 2$ and expressed in $\mathrm{kg}^{0.75} / \mathrm{fish}$; branchial and urinary energy loss (BUE) was calculated as $(($ digestible $\mathrm{N}$ intake $(\mathrm{DNI})-\mathrm{N}$ gain $) \times 24 \cdot 85) / 1000$, where 24.85 is the amount of energy equivalent to $1 \mathrm{~g}$ excreted $\mathrm{N}$.

From these variables, the following response criteria were calculated:

Body weight gain $(\mathrm{g} / \mathrm{kg}$ MBW per $\mathrm{d})=\left(W_{\mathrm{f}}-W_{\mathrm{i}}\right) /(\mathrm{MBW} \times \Delta \mathrm{t})$. Thermal growth coefficient (TGC) $\left(\mathrm{g}^{1 / 3}\right.$ per $\mathrm{d}$ and per ${ }^{\circ} \mathrm{C}, \times$ $1000)=1000 \times\left(W_{\mathrm{f}}^{1 / 3}-\mathrm{W}_{\mathrm{i}}^{1 / 3}\right) /(\Delta \mathrm{t} \times$ temperature $)$. 
Feed efficiency $(\mathrm{FE})(\mathrm{g} / \mathrm{g} \mathrm{DM})=\left(W_{\mathrm{f}}-W_{\mathrm{i}}\right) / D_{\mathrm{i}}$.

Protein efficiency ratio $(\mathrm{PER})(\mathrm{g} / \mathrm{g})=100 \times\left(W_{\mathrm{f}}-W_{\mathrm{j}}\right) /\left(D_{\mathrm{i}} \times \mathrm{N}_{\mathrm{d}} \times 6 \cdot 25\right)$.

$\mathrm{N}$ gain $(\mathrm{mg} / \mathrm{kg}$ MBW per $\mathrm{d})=1000 \times\left(W_{\mathrm{f}} \times \mathrm{N}_{\mathrm{f}}-W_{\mathrm{i}} \times \mathrm{N}_{\mathrm{i}}\right) /$ $(\mathrm{MBW} \times \Delta t)$.

Lys intake $(\mathrm{mg} / \mathrm{kg} \mathrm{MBW}$ per $\mathrm{d})=1000 \times D_{\mathrm{i}} \times \mathrm{Lys}_{\mathrm{d}} /(\mathrm{MBW} \times \Delta t)$.

DE intake (DEI) $\left(\mathrm{kJ} / \mathrm{kg}\right.$ MBW per d) $=D_{\mathrm{i}} \times \mathrm{DE}_{\mathrm{d}} /(\mathrm{MBW} \times \Delta t)$.

Digestible $\mathrm{N}$ intake $(\mathrm{DNI})\left(\mathrm{mg} / \mathrm{kg} \mathrm{MBW}\right.$ per d) $=1000 \times D_{\mathrm{i}} \times N_{\mathrm{d}} /$ $(\mathrm{MBW} \times \Delta t)$.

VFI $($ g DM/kg MBW per $\mathrm{d})=D_{\mathrm{i}} /(\mathrm{MBW} \times \Delta t)$.

$\mathrm{N}$ retention efficiency $(\mathrm{NRE})(\%)=100 \times \mathrm{N}$ gain $/ \mathrm{N}$ intake.

GE gain $(\mathrm{kJ} / \mathrm{kg} \mathrm{MBW}$ per $\mathrm{d})=\left(W_{\mathrm{f}} \times \mathrm{GE}_{\mathrm{f}}-W_{\mathrm{i}} \times \mathrm{GE}_{\mathrm{i}}\right) /(\mathrm{MBW} \times \Delta t)$.

Heat production $(\mathrm{kJ} / \mathrm{kg}$ MBW per $\mathrm{d})=\mathrm{DEI}-\mathrm{BUE}-\mathrm{GE}$ gain.

\section{Data analysis}

The linear model used was the broken-line model (BLM) ${ }^{(32,33)}$ :

$$
y=P+U \times(x-R) \times Z+\varepsilon
$$

where $y$ is the response; $P$ the plateau value; $U$ the slope; $R$ the requirement; $x$ the independent variable; $Z$ is a categorical variable which equals 0 when $x>R$ and 1 otherwise; $\varepsilon$ is the error term. The $x$-intercept was calculated as $R-P / U$.

The broken-line model was fitted in a Bayesian framework ${ }^{(34)}$. Non-informative prior distributions were chosen for each model parameter. The posterior chains were computed using the JAGS package ${ }^{(35)}$ in $\mathrm{R}$ statistical software, version 3.1.2. Convergence of the chains was assessed by examining the trace plots and the Geweke diagnostics ${ }^{(36)}$. The presented values are the mean posterior of the parameter.

Inference on model parameters was performed using the posterior chains. The level of significance was set at $5 \%$. The differences were considered significant when 0 was not contained in the $95 \%$ credible interval $(95 \% \mathrm{CI})$ of the posterior distribution. The CI limits were determined according to Bonferroni correction. In the manuscript, a significant increase with DP (DE) level means that the values were significantly higher for a high DP (DE) level compared with a lower level for a same DE (DP) level. In brief, values of HP (HE) diets were significantly higher than for MP (ME) diets and those for MP (ME) diets are significantly higher than for LP (LE) diets.

Similar analyses were performed with the four-parameter logistic model $^{(37)}$ :

$$
y=\left(R_{\max }+\left(b \times(1+c)-R_{\max }\right) \times d^{x}\right) /\left(1+c \times d^{x}\right),
$$

where $y$ is the response; $R_{\max }$ the plateau value; $b$ the $y$-intercept; $c$ the shaping parameter that locates the inflection point; $d$ the scaling parameter; $x$ the independent variable. The requirement was defined as the level at which $95 \%$ of the maximum response was achieved $\left(0.95 \times R_{\max }\right)$.

The results led to the same conclusions. The Akaike Information Criterion with correction (AICc) was calculated using GraphPad Prism 6.0 (GraphPad Software) and, for all regressions excepted the regressions for HPLE diets relating to the TGC or GE gain and the dietary Lys level (g/kg DM), AICc were lower for the BLM compared with the four-parameter logistic model (data not shown). Therefore, the BLM has been selected for the present study. The results obtained with the four-parameter logistic model are available in appendix (online Supplementary Table S5).

For each dietary protein and energy concentrations, a simple linear regression analysis was calculated to estimate the relationship between the requirement estimates with the BLM ( $\mathrm{R}$ parameter) and the dietary energy level:

$$
y=A+B \times x,
$$

where $y$ is the response, $A$ the intercept of the linear regression, $B$ the slope and $x$ the dietary energy level. Linear regression analysis was performed using GraphPad Prism 6.0 (GraphPad Software). The comparison of slope parameters was determined by comparing the slope confidence intervals according to the Bonferroni correction (three groups). In the manuscript, a significant linear increase is related to a straight-line linear regression model.

\section{Results}

\section{Growth and body composition}

Mean mortality was low during the two trials (three fish per aquarium). The Lys-deficient diets showed higher mortality rates (data not shown). Indeed, a mean mortality of nine fish per aquarium was observed in fish fed on diets containing the lowest Lys concentration. For all other diets, the average mortality was of two fish per aquarium.

By the end of the experiment, fry fed LP5 to LP9, MP5 to MP9 and HP7 to HP9 diets increased their mean initial body weight by a factor of at least four, whatever the dietary DE level (data not shown). Body weight gain, TGC, FE and PER gradually increased with the dietary Lys concentration until a plateau was reached or approached (online Supplementary Table S2).

In the present study, the relationships between TGC and dietary Lys concentration were interpreted using the rectilinear BLM (Fig. 1, Table 4). The plateau value of the BLM was similar with fish fed MP and HP diets $(0 \in 95 \% \mathrm{CI})$, and both values were significantly higher than with fry fed LP diets (Table 4). However, that plateau was not affected by dietary DE content $(0 \in 95 \% \mathrm{CI})$. Also, the relative Lys requirement $(\mathrm{g} / \mathrm{kg} \mathrm{DM})$ for maximum TGC increased significantly with the DP level but was unaffected by dietary DE concentration $(0 \in 95 \% \mathrm{CI}$ ) (Table 4). In brief, it varied from 13.3 (LPLE) $-15 \cdot 1 \mathrm{~g} / \mathrm{kg}$ DM (LPHE) to $17 \cdot 4$ (MPLE) $-16 \cdot 0 \mathrm{~g} / \mathrm{kg}$ DM (MPHE) and then to 22.3 (HPLE) $-24 \cdot 0$ (HPHE) g/kg DM for fish fed LP, MP and HP diets, respectively.

The proximate composition of the fish whole bodies is shown in the online Supplementary Table S4. CP and GE contents of final fry increased with Lys concentration. The lipid content was mostly not linearly related to dietary Lys level but increased with increasing dietary DE level for a same dietary DP level. The highest body fat content was observed in fry fed LPME or LPHE diets. As expected, final fish GE contents increased with increasing dietary DE levels for all diets (except HPHE1).

\section{Nitrogen gain}

$\mathrm{N}$ gain $(\mathrm{mg} / \mathrm{kg}$ MBW per $\mathrm{d})$ was fitted to the BLM against the dietary Lys concentration, expressed in $\mathrm{g} / \mathrm{kg}$ DM diet (Fig. 2, Table 4). Plateau value significantly increased with increasing 
(a)

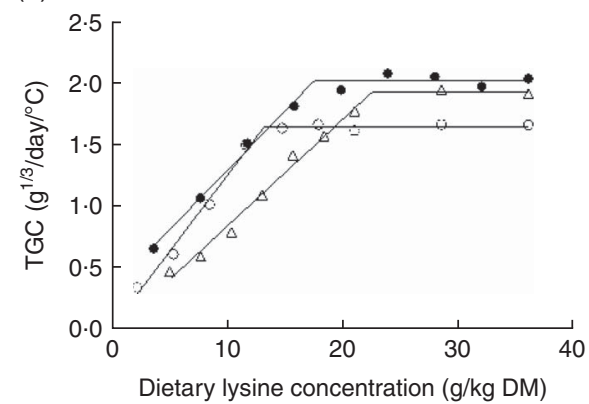

(b)

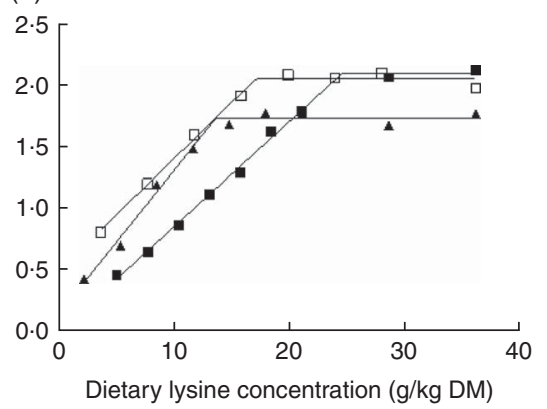

(c)

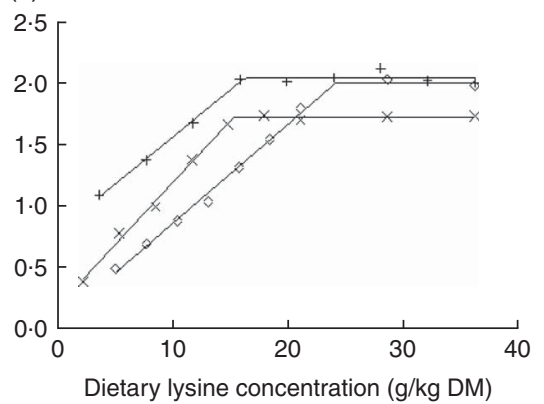

Fig. 1. Thermal growth coefficient (TGC; $1000 \times\left((\text { final body weight })^{1 / 3}-(\text { initial body weight })^{1 / 3}\right) /\left(\right.$ feeding days $\times$ temperature); $g^{1 / 3}$ per $\left.d\right)$ plotted against dietary lysine (Lys) concentration ( $\mathrm{g} / \mathrm{kg} \mathrm{DM}$ ) and modelled with the broken-line model for three dietary digestible protein (DP) levels (low protein (LP), medium protein (MP) and high protein (HP) containing 280, 440 and $600 \mathrm{~g} \mathrm{DP} / \mathrm{kg} \mathrm{DM}$, respectively) and three dietary digestible energy (DE) levels (low energy (LE), medium energy (ME) and high energy (HE) containing 17, 19.5 and 22 MJ DE/kg DM, respectively). (a) O, LPLE; $\bullet$, MPLE; $\Delta$, HPLE; (b) $\mathbf{\Delta}$, LPME; $\square$, MPME; $\mathbf{\square}$, HPME; (c) $\times$, LPHE; +, MPHE; $\diamond$, HPHE. Each data point represents the result of one aquarium with fifty initial fish (rainbow trout of initial body weight $0.85 \mathrm{~g} /$ fish reared at $11.6^{\circ} \mathrm{C}$ for a 24 or a $30-\mathrm{d}$ feeding period for MP (trial 2) or LP and HP (trial 1) diets, respectively). Parameters of the model are shown in Table 4.

dietary DP concentration at the same DE level, except between MPHE and HPHE. In this case, a tendency was observed (95\% CI: $-40 \cdot 3,1.4)$. No significant differences were found between DE levels for a same DP level $(0 \in 95 \% \mathrm{CI})$. The slope of the BLM tended to decrease with increasing dietary DP contents for a same DE level and similarly with increasing DE level for a same diet DP concentration. Still, the differences were only significant between LPME and HPME and between LPHE and HPHE diets (Table 4).

At a same DE level, the relative Lys requirement for maximum $\mathrm{N}$ gain, expressed as g Lys/kg dry diet, was significantly greater for the HP diets compared with MP diets and significantly higher for MP diets compared with LP diets. It increased from 13.3 to 22.9 (+ 9.6) g Lys $/ \mathrm{kg} \mathrm{DM}$, from 14.9 to 24.6 (+9.7) $\mathrm{g}$ Lys/kg DM and from 15.7 to $26 \cdot 5$ (+ 10.8) g Lys/kg DM, for LE, ME and HE diets respectively (Table 4, Fig. 3). On the other hand, the comparison of requirements showed no significant effect of dietary DE concentrations on the relative Lys requirement for maximum $\mathrm{N}$ gain (g/kg DM) (Table 4, Fig. 3). By contrast, a visual observation of Fig. 3 shows that the relative Lys requirement $(\mathrm{g} / \mathrm{kg} \mathrm{DM})$ tended to increase linearly with increasing DE levels for a same DP content. However, this DE main effect was relatively small (9-18\%) compared with the DP effect $(+66-72 \%)$ and the linear increase was only significant for fish fed HP diets $(P=0.02$, Fig. 3). For LP or MP diets, the requirement estimates did not increase linearly with the dietary energy level $(P>0 \cdot 10)$. Moreover, a test of equal slopes showed no significant differences among LP, MP and HP diets.

When expressing the relative Lys requirement in terms of percentage of dietary DP ( $\mathrm{g}$ Lys/16 $\mathrm{g} \mathrm{N}$ ) and modelling the data with the BLM (Fig. 4, Table 4), the requirements were not significantly different in fish fed MP and HP diets, whatever the DE level considered. However, the requirements found in fish fed LP diets were significantly greater than the requirements estimated in fish fed MP or HP diets, regardless of the energy level considered (Table 4). On the other hand, the relative Lys requirement $(\mathrm{g} / 16 \mathrm{~g} \mathrm{~N})$ tended to increase linearly with increasing DE levels for a same DP content (Fig. 5), but these linear increases were relatively small (10-20\%) and only significant for HP conditions $(P=0.01)$. In LP or MP diets, the requirement estimates did not increase linearly with $\mathrm{DE}$ level
$(P>0 \cdot 10)$. Again, the slopes were not significantly different between LP, MP and HP diets.

The absolute Lys requirements ( $\mathrm{mg} / \mathrm{kg}$ MBW per $\mathrm{d}$ ) for maximum $\mathrm{N}$ deposition estimated for LP diets were not significantly different from those estimated for MP diets (Fig. 6, Table 5). Fry fed HPHE diets showed a significantly greater absolute requirement than those fed LP and MP diets $(0 \notin 95 \%$ CI) except in the case of the MPHE diets. Fry fed HPLE diets had a significantly higher absolute requirement estimate than those fed LPLE, LPME and MPLE diets (Table 5). By contrast, the absolute Lys requirement did not significantly increase or decrease linearly with the dietary DE concentration (Fig. 7). Interestingly, the slope of the BLM, representing the efficiency of Lys utilisation for $\mathrm{N}$ deposition above maintenance, remained fairly constant $(0 \in 95 \% \mathrm{CI})$ regardless of the diet (except between LPME and HPHE diets (95\% CI 0.01, 0.66)). These results suggest that neither the protein level nor the energy level did influence Lys utilisation efficiency for protein growth above maintenance. Similar results were found with the $x$-intercept of the BLM, the Lys maintenance requirement for a null $\mathrm{N}$ gain. However, values were not positive for MP and HP diets and the Lys maintenance requirement could not be calculated for these diets.

Slope inverse value of the linear regressions of protein gain $(\mathrm{N}$ gain $\times 6.25) \quad(\mathrm{mg} / \mathrm{kg}$ MBW per d) against Lys intake (mg Lys/kg MBW per d) was calculated for the Lys-deficient diets (LP1-4 or $<11.63 \mathrm{~g}$ Lys/kg DM, MP1-4 or $<15.79 \mathrm{~g}$ Lys $/ \mathrm{kg}$ DM and HP1-6 or $<18.35 \mathrm{~g}$ Lys/kg DM) (Table 6), giving the estimated amounts of Lys required to deposit $1 \mathrm{~g}$ body protein. Neither the slopes of the lines nor the Lys required for $1 \mathrm{~g}$ protein deposition did significantly vary with dietary DP or DE levels $(0 \in 95 \% \mathrm{CI})$. For all diets, the mean Lys requirement to deposit $1 \mathrm{~g}$ body protein turned about $113 \cdot 1 \mathrm{mg}$ Lys (95\% slope inverse CI 107.4, 119.1).

NRE (\%) was modelled against Lys intake ( $\mathrm{mg} / \mathrm{kg}$ MBW per d) with the BLM (Table 5). The plateau value was not significantly affected by dietary DE level for a same protein level $(0 \in 95 \% \mathrm{CI})$. Furthermore, it decreased with increasing DP level (except between MPHE and HPHE) and was significantly higher for LPLE and LPME diets compared with MP or HP diets. 
Table 4. Parameters estimated by fitting the experimental data to a broken-line regression at each protein and energy levels for the response criteria of

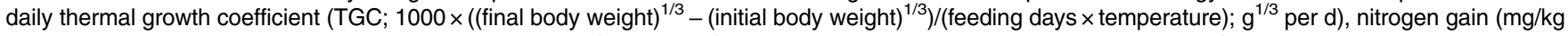
metabolic body weight (MBW) per d), gross energy gain (GE gain; kJ/kg MBW per d), voluntary feed intake (VFl; g DM/kg MBW per d), digestible energy intake (DEl; kJ/kg MBW per d) and digestible $\mathrm{N}$ intake (DNI; $\mathrm{mg} / \mathrm{kg} \mathrm{MBW}$ per d)*

\begin{tabular}{|c|c|c|c|c|c|c|}
\hline \multirow[b]{2}{*}{ Lys requirement in terms of } & \multirow[b]{2}{*}{ Criteria } & \multirow[b]{2}{*}{ Diets } & \multicolumn{4}{|c|}{ Broken-line model parameters } \\
\hline & & & $P$ & $U$ & $R$ & $x$-intercept \\
\hline Dietary Lys level $(\mathrm{g} / 16 \mathrm{gN})$ & GE gain & $\begin{array}{l}\text { LPLE } \\
\text { LPME } \\
\text { LPHE } \\
\text { MPLE } \\
\text { MPME } \\
\text { MPHE } \\
\text { HPLE } \\
\text { HPME } \\
\text { HPHE } \\
\text { LPLE } \\
\text { LPME } \\
\text { LPHE } \\
\text { MPLE } \\
\text { MPME } \\
\text { MPHE } \\
\text { HPLE } \\
\text { HPME } \\
\text { HPHE } \\
\text { LPLE } \\
\text { LPME } \\
\text { LPHE } \\
\text { MPLE } \\
\text { MPME } \\
\text { MPHE } \\
\text { HPLE } \\
\text { HPME } \\
\text { HPHE } \\
\text { LPLE } \\
\text { LPME } \\
\text { LPHE } \\
\text { MPLE } \\
\text { MPME } \\
\text { MPHE } \\
\text { HPLE } \\
\text { HPME } \\
\text { HPHE } \\
\text { LPLE } \\
\text { LPME } \\
\text { LPHE } \\
\text { MPLE } \\
\text { MPME } \\
\text { MPHE } \\
\text { HPLE } \\
\text { HPME } \\
\text { HPHE } \\
\text { LPLE } \\
\text { LPME } \\
\text { LPHE } \\
\text { MPLE } \\
\text { MPME } \\
\text { MPHE } \\
\text { HPLE } \\
\text { HPME } \\
\text { HPHE } \\
\text { LPLE } \\
\text { LPME } \\
\text { LPHE } \\
\text { MPLE } \\
\text { MPME } \\
\text { MPHE } \\
\text { HPLE } \\
\text { HPME } \\
\text { HPHE }\end{array}$ & 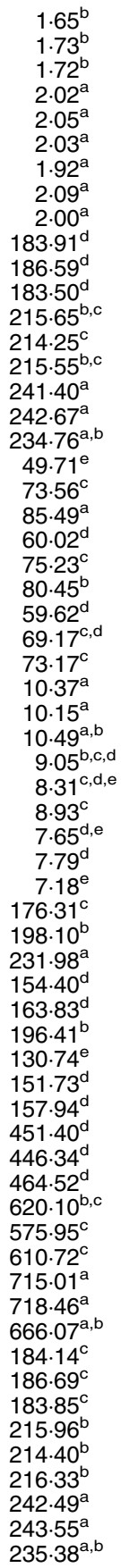 & $\begin{array}{c}0 \cdot 12^{\mathrm{a}} \\
0 \cdot 12^{\mathrm{a}, \mathrm{b}} \\
0 \cdot 10^{\mathrm{a}, \mathrm{b}, \mathrm{c}} \\
0 \cdot 10^{\mathrm{a}, \mathrm{b}, \mathrm{c}, \mathrm{d}} \\
0 \cdot 09^{\mathrm{a}, \mathrm{b}, \mathrm{c}, \mathrm{d}} \\
0 \cdot 08^{\mathrm{c}, \mathrm{d}} \\
0 \cdot 09^{\mathrm{b}, \mathrm{c}, \mathrm{d}} \\
0 \cdot 09^{\mathrm{d}} \\
0 \cdot 08^{\mathrm{d}} \\
15 \cdot 58^{\mathrm{a}, \mathrm{b}, \mathrm{c}} \\
14 \cdot 60^{\mathrm{a}} \\
13 \cdot 24^{\mathrm{a}, \mathrm{b}} \\
12 \cdot 92^{\mathrm{a}, \mathrm{b}, \mathrm{c}} \\
12 \cdot 22^{\mathrm{a}, \mathrm{b}, \mathrm{c}} \\
9 \cdot 60^{\mathrm{b}, \mathrm{c}} \\
12 \cdot 27^{\mathrm{a}, \mathrm{b}, \mathrm{c}} \\
11 \cdot 69^{\mathrm{b}, \mathrm{c}} \\
9 \cdot 98^{\mathrm{c}} \\
4 \cdot 08^{\mathrm{a}, \mathrm{b}} \\
5 \cdot 45^{\mathrm{a}} \\
6 \cdot 19^{\mathrm{a}} \\
2 \cdot 96^{\mathrm{b}} \\
3 \cdot 50^{\mathrm{b}} \\
3 \cdot 38^{\mathrm{b}} \\
3 \cdot 32^{\mathrm{b}} \\
3 \cdot 34^{\mathrm{b}} \\
3 \cdot 11^{\mathrm{b}} \\
0 \cdot 53^{\mathrm{b}} \\
0 \cdot 43^{\mathrm{b}} \\
0 \cdot 42^{\mathrm{a}, \mathrm{b}, \mathrm{c}} \\
0 \cdot 32^{\mathrm{a}, \mathrm{b}, \mathrm{c}} \\
0 \cdot 47^{\mathrm{a}, \mathrm{b}, \mathrm{c}} \\
0 \cdot 10^{\mathrm{c}} \\
0 \cdot 31^{\mathrm{a}, \mathrm{b}, \mathrm{c}} \\
0 \cdot 25^{\mathrm{b}} \\
0 \cdot 25^{\mathrm{b}} \\
8 \cdot 81^{\mathrm{a}} \\
8 \cdot 23^{\mathrm{a}, \mathrm{b}} \\
7 \cdot 35^{\mathrm{a}, \mathrm{b}, \mathrm{c}} \\
4 \cdot 75^{\mathrm{a}, \mathrm{b}, \mathrm{c}} \\
5 \cdot 80^{\mathrm{a}, \mathrm{b}, \mathrm{c}} \\
2 \cdot 21^{\mathrm{d}} \\
4 \cdot 86^{\mathrm{b}, \mathrm{c}} \\
4 \cdot 80^{\mathrm{c}} \\
5 \cdot 42^{\mathrm{c}} \\
21 \cdot 78^{\mathrm{a}} \\
17 \cdot 71^{\mathrm{a}} \\
13 \cdot 69^{\mathrm{a}, \mathrm{b}} \\
16 \cdot 99^{\mathrm{a}, \mathrm{b}} \\
17 \cdot 05^{\mathrm{a}, \mathrm{b}} \\
6 \cdot 31^{\mathrm{b}} \\
23 \cdot 88^{\mathrm{a}} \\
22 \cdot 19^{\mathrm{a}} \\
22 \cdot 43^{\mathrm{a}} \\
40 \cdot 14^{\mathrm{b}, \mathrm{c}} \\
36 \cdot 74^{\mathrm{c}} \\
33 \cdot 19^{\mathrm{c}} \\
60 \cdot 33^{\mathrm{a}, \mathrm{b}} \\
57 \cdot 1^{\mathrm{a}, \mathrm{b}} \\
44 \cdot 05^{\mathrm{b}, \mathrm{c}} \\
66 \cdot 96^{\mathrm{a}} \\
63 \cdot 67^{\mathrm{a}} \\
54 \cdot 44^{\mathrm{a}, \mathrm{b}}\end{array}$ & $\begin{array}{l}13 \cdot 25^{\mathrm{d}} \\
13 \cdot 70^{\mathrm{c}, \mathrm{d}} \\
15 \cdot 13^{\mathrm{b}, \mathrm{c}, \mathrm{d}} \\
17 \cdot 44^{\mathrm{b}} \\
16 \cdot 87^{\mathrm{b}, \mathrm{c}} \\
16 \cdot 05^{\mathrm{b}, \mathrm{c}, \mathrm{d}} \\
22 \cdot 33^{\mathrm{a}} \\
24 \cdot 38^{\mathrm{a}} \\
24 \cdot 02^{\mathrm{a}} \\
13 \cdot 32^{\mathrm{e}} \\
14 \cdot 87^{\mathrm{e}} \\
15 \cdot 71^{\mathrm{d}, \mathrm{e}} \\
18 \cdot 51^{\mathrm{c}, \mathrm{d}} \\
18 \cdot 36^{\mathrm{c}, \mathrm{d}} \\
20 \cdot 26^{\mathrm{b}, \mathrm{c}} \\
22 \cdot 93^{\mathrm{a}, \mathrm{b}} \\
24 \cdot 63^{\mathrm{a}, \mathrm{b}} \\
26 \cdot 49^{\mathrm{a}} \\
11 \cdot 84^{\mathrm{d}, \mathrm{e}} \\
13 \cdot 05^{\mathrm{e}} \\
12 \cdot 86^{\mathrm{e}} \\
16 \cdot 71^{\mathrm{c}} \\
17 \cdot 67^{\mathrm{b}, \mathrm{c}} \\
16 \cdot 09^{\mathrm{c}, \mathrm{d}} \\
19 \cdot 94^{\mathrm{b}} \\
22 \cdot 60^{\mathrm{b}} \\
23 \cdot 02^{\mathrm{a}} \\
11 \cdot 96^{\mathrm{b}} \\
14 \cdot 22^{\mathrm{b}} \\
14 \cdot 35^{\mathrm{b}, \mathrm{c}} \\
17 \cdot 86^{\mathrm{a}, \mathrm{b}} \\
11 \cdot 06^{\mathrm{b}} \\
22 \cdot 39^{\mathrm{a}, \mathrm{b}} \\
18 \cdot 47^{\mathrm{a}, \mathrm{b}} \\
23 \cdot 08^{\mathrm{a}} \\
22 \cdot 04^{\mathrm{a}} \\
12 \cdot 05^{\mathrm{e}} \\
14 \cdot 31^{\mathrm{d}, \mathrm{e}} \\
15 \cdot 32^{\mathrm{c}, \mathrm{d}, \mathrm{e}} \\
18 \cdot 73^{\mathrm{a}, \mathrm{b}, \mathrm{c}, \mathrm{d}, \mathrm{e}} \\
13 \cdot 88^{\mathrm{b}, \mathrm{c}, \mathrm{d}, \mathrm{e}} \\
22 \cdot 38^{\mathrm{a}, \mathrm{b}, \mathrm{c}} \\
19 \cdot 27^{\mathrm{a}, \mathrm{b}, \mathrm{c}, \mathrm{d}} \\
23 \cdot 04^{\mathrm{a}} \\
22 \cdot 09^{\mathrm{a}, \mathrm{b}} \\
12 \cdot 11^{\mathrm{c}} \\
14 \cdot 37^{\mathrm{b}, \mathrm{c}} \\
15 \cdot 04^{\mathrm{b}, \mathrm{c}} \\
18 \cdot 95^{\mathrm{a}, \mathrm{b}, \mathrm{c}} \\
14 \cdot 53^{\mathrm{a}, \mathrm{b}, \mathrm{c}} \\
21 \cdot 55^{\mathrm{a}, \mathrm{b}} \\
19 \cdot 23^{\mathrm{a}, \mathrm{b}, \mathrm{c}} \\
22 \cdot 88^{\mathrm{a}} \\
21 \cdot 87^{\mathrm{a}} \\
5 \cdot 27^{\mathrm{a}, \mathrm{b}} \\
5 \cdot 94^{\mathrm{a}} \\
6 \cdot 30^{\mathrm{a}} \\
4 \cdot 11^{\mathrm{b}} \\
4 \cdot 07^{\mathrm{b}} \\
4 \cdot 54^{\mathrm{b}} \\
4 \cdot 21^{\mathrm{b}} \\
4 \cdot 52^{\mathrm{b}} \\
4 \cdot 85^{\mathrm{b}} \\
\end{array}$ & 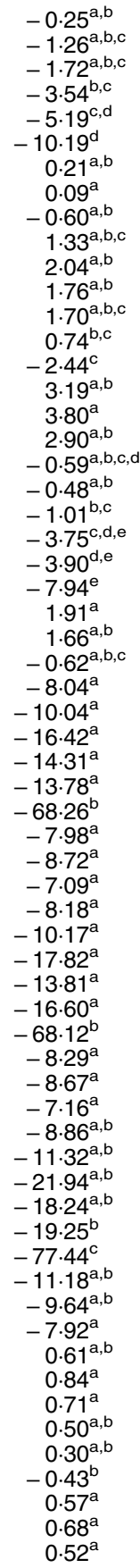 \\
\hline
\end{tabular}

LP, low-protein diets (280 g digestible protein (DP)/kg DM; MP, medium-protein diets (440 g DP/kg DM); HP, high-protein diets (600 g DP/kg DM); LE, low-energy diets (17 MJ digestible energy (DE)/kg DM); ME, medium-energy diets (19.5 MJ DE/kg DM); HE, high-energy diets (22 MJ DE/kg DM); MBW, MBW=((initial body weight) ${ }^{0.75}+($ final body weight $\left.{ }^{0.75}\right) / 2 ; P$, plateau value; $U$, slope; $R$, requirement.

a,b,c,d,e Values within a column with unlike superscript letters for a same response criterion were significantly different $(0 \notin 95 \% \mathrm{Cl})$.

* For the details of procedures and diets, see Tables 1 and 2 and the 'Methods' section. Values are from one aquarium containing initially fifty fry of $0.85 \mathrm{~g}$ mean initial body weight. Fish were kept at a temperature of $11 \cdot 6 \pm 0.3^{\circ} \mathrm{C}$. 
(a)

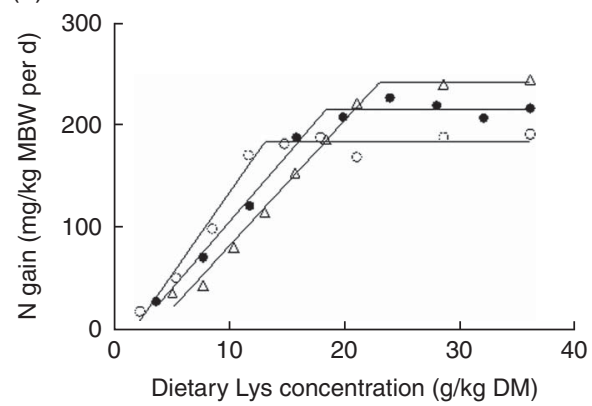

(b)

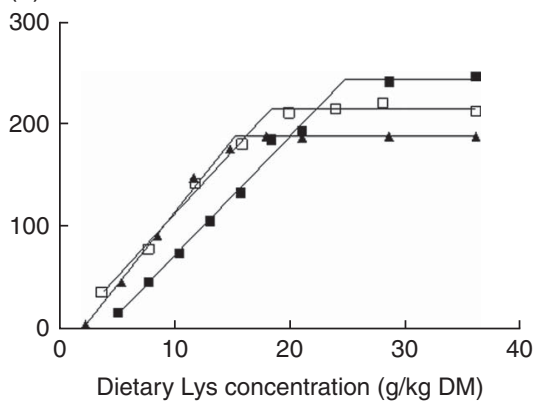

(c)

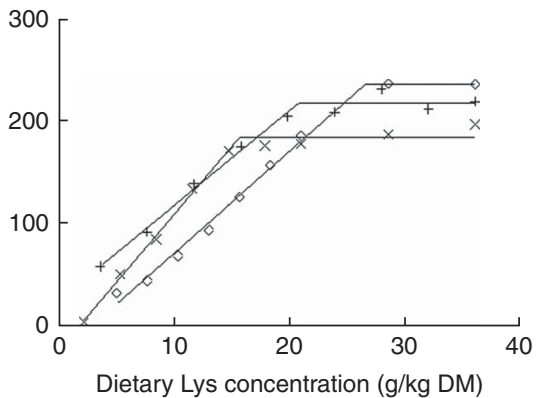

Fig. 2. Relative lysine (Lys) requirement ( $\mathrm{g} / \mathrm{kg}$ dry diet) for maximum $\mathrm{N}$ gain estimated with a broken-line model for three dietary digestible protein (DP) levels (low protein (LP), medium protein (MP) and high protein (HP) containing 280, 440 and $600 \mathrm{~g} \mathrm{DP} / \mathrm{kg} \mathrm{DM}$, respectively) and three dietary digestible energy (DE) levels (low energy (LE), medium energy (ME) and high energy (HE) containing 17, 19.5 and $22 \mathrm{MJ}$ DE/kg DM, respectively). (a) O, LPLE; $\mathbf{0}$, MPLE; $\triangle$, HPLE; (b) $\mathbf{A}$, LPME; $\square$, MPME; $\square$, HPME; (c) $\times$, LPHE; + , MPHE; $\diamond$, HPHE. Each data point represents the result of one aquarium with fifty initial fish (rainbow trout of initial body weight $0.85 \mathrm{~g} /$ fish reared at $11.6^{\circ} \mathrm{C}$ for a 24 or a $30-\mathrm{d}$ feeding period for MP (trial 2) or LP and HP (trial 1) diets, respectively). Parameters of the model are shown in Table 4. Metabolic body weight $(\mathrm{MBW})=\left((\text { initial body weight })^{0.75}+(\text { final body weight })^{0.75}\right) / 2$.

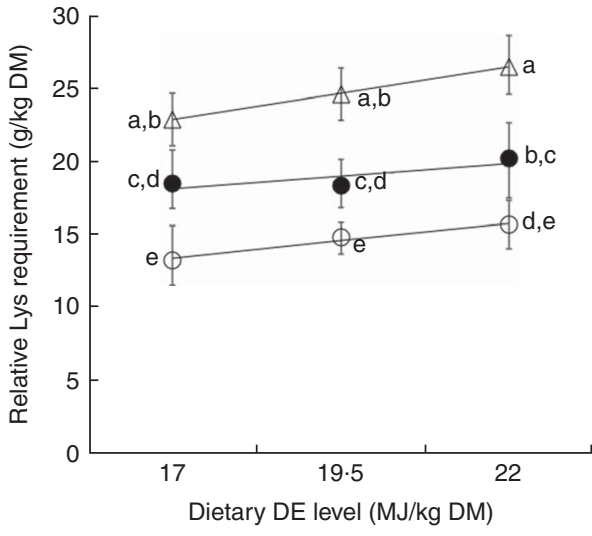

Fig. 3. Relative lysine (Lys) requirement estimates ( $\mathrm{g}$ Lys/kg DM; means and $95 \%$ credible intervals of the posterior parameters) for maximum nitrogen gain, plotted against dietary digestible energy (DE) levels (17, 19.5 and $22 \mathrm{MJ} \mathrm{DE} / \mathrm{kg}$ $\mathrm{DM}$ ) and modelled with a linear regression for three dietary digestible protein (DP) levels: $280 \mathrm{~g} \mathrm{DP} / \mathrm{kg} \mathrm{DM}$ (low protein (LP), O), $Y=5.32$ (SE 1.63) +0.48 (SE 0.08) $X\left(n 3, r^{2} 0.97, P=0.11\right) ; 440 \mathrm{~g} \mathrm{DP} / \mathrm{kg} \mathrm{DM}$ (medium protein (MP), $\bullet$ ), $Y=12.24$ (SE 4.63) +0.35 (SE 0.24) $X\left(n 3, r^{2} 0.69, P=0.38\right)$; and $600 \mathrm{~g} \mathrm{DP} / \mathrm{kg}$ $\mathrm{DM}$ (high protein (HP), $\Delta$ ) $Y=10.82$ (SE 0.36) +0.71 (SE 0.02) $X\left(n 3, r^{2} 1.00\right.$, $P=0.02)$. No significant differences were observed between slopes of the three regressions $(P>0.05)$. Each data point represents estimates calculated with nine aquarium of fifty initial fish (rainbow trout of initial body weight $0.85 \mathrm{~g} /$ fish reared at $11.6^{\circ} \mathrm{C}$ for a 24 or a $30-d$ feeding period for MP (trial 2) or LP and HP (trial 1) diets, respectively). ${ }^{\mathrm{a}, \mathrm{b}, \mathrm{c}, \mathrm{d}, \mathrm{e}}$ Mean values with unlike letters of the requirement estimates were significantly different $(0 \notin 95 \% \mathrm{Cl})$.

\section{Energy gain}

Energy deposition ( $\mathrm{kJ} / \mathrm{kg}$ MBW per d) was positively related to the dietary Lys concentration $(\mathrm{g} / \mathrm{kg} \mathrm{DM})$ until a plateau value was reached (online Supplementary Table S3). The plateau value of the BLM was affected by both the DP and the DE density of the diets (Table 4). The highest plateau value was reached in fish fed LPHE diets $(0 \notin 95 \% \mathrm{CI})$. For a same dietary protein level, GE gain significantly increased with increasing dietary DE level.

\section{Voluntary feed intake}

VFI (g DM/kg MBW per d) progressively increased with increasing dietary Lys concentration until a plateau was reached (online Supplementary Tables S3 and S4). The comparison of BLM plateau values indicated that there was no significant differences between energy levels for a same dietary protein concentration $(0 \in 95 \% \mathrm{CI})$, except between HPME and HPHE (95\% CI 0.04, 1.13). By contrast, VFI decreased with increasing DP level for a same DE density, but the observed differences were not significant between some diets (MPLE and HPLE; MPME and HPME diets).

When daily DEI (kJ/kg MBW per d) was considered (online Supplementary Tables S3 and S4, Fig. 8), maximum DEI (plateau value) was related to both dietary DP and DE contents. Indeed, the plateau value significantly decreased with increasing dietary DP level for a same DE level, except between MPME and HPME diets $(95 \% \mathrm{CI}-1 \cdot 0,25.9)$. On the other hand, the plateau value significantly increased with increasing dietary DE level for a same DP level, except between MPLE and MPME and between HPME and HPHE diets $(0 \in 95 \% \mathrm{CI})$. By contrast, no significant effect of diet DE content was noticed on daily DNI (mg/kg MBW per d), whatever the DP level considered. Furthermore, N intake plateau values significantly increased with increasing diet DP content, except between MPLE and HPHE diets (95\% CI -115.5, 5.8).

\section{Heat production}

Heat production $(\mathrm{kJ} / \mathrm{kg}$ MBW per $\mathrm{d})$ results estimated from DEI, DNI, $\mathrm{N}$ gain and GE gain are presented in Table 7 . Values increased linearly with the dietary Lys level $(P<0.02)$, except in the LPHE, MPME and MPHE diets. For a same Lys level and a same dietary energy content, the heat production decreased with the dietary DP level (except between MPLE1 and HPLE1 and between LPHE1 and MPHE1). Moreover, for a same Lys level, an increase in heat production with increasing dietary DE level was observed but only between the two extreme dietary DE levels (LE and HE), except in HP1 and HP3. In general, the highest values were observed for the LPHE fed fry.

\section{Discussion}

The present study tested the effect of increasing both dietary DP and DE levels on the relative and absolute Lys requirements, the Lys utilisation efficiency for protein growth (above maintenance) 
(a)

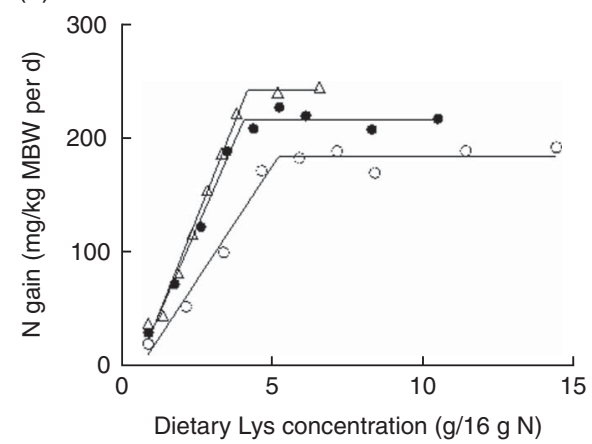

(b)

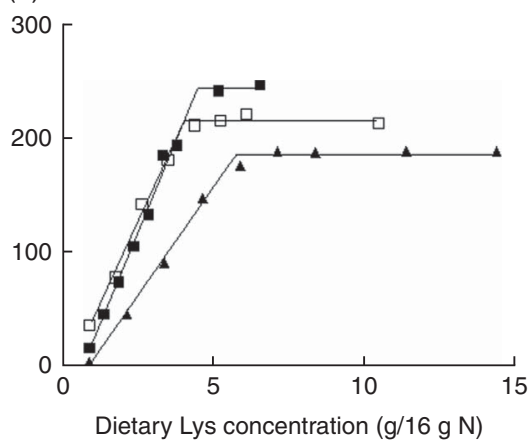

(c)

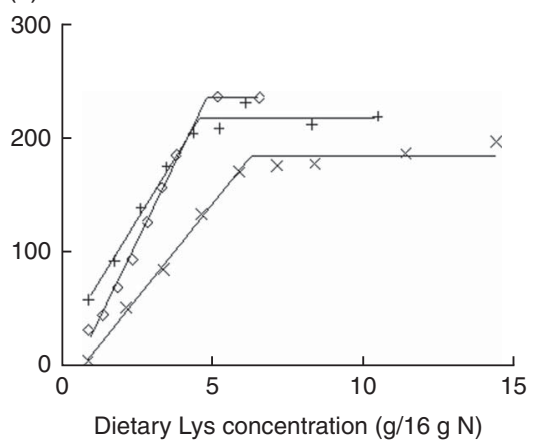

Fig. 4. Relative lysine (Lys) requirement (g/16 g nitrogen) for maximum nitrogen gain estimated with a broken-line model for three dietary digestible protein (DP) levels (low protein (LP), medium protein (MP) and high protein (HP) containing 280, 440 and $600 \mathrm{~g} \mathrm{DP} / \mathrm{kg}$ DM, respectively) and three dietary digestible energy (DE) levels (low energy (LE), medium energy (ME) and high energy (HE) containing 17, 19.5 and 22 MJ DE/kg DM, respectively). (a) O, LPLE;, MPLE; $\triangle$, HPLE; (b) $\mathbf{A}$, LPME; $\square$, MPME; $\boldsymbol{\square}$, HPME; (c) $\times$, LPHE; +, MPHE; $\diamond$, HPHE. Each data point represents the result of one aquarium with fifty initial fish (rainbow trout of initial body weight $0.85 \mathrm{~g} /$ fish reared at $11.6^{\circ} \mathrm{C}$ for a 24 or a 30 -d feeding period for MP (trial 2) or LP and HP (trial 1) diets, respectively). Parameters of the model are shown in Table 4. Metabolic body weight $(\mathrm{MBW})=\left((\text { initial body weight })^{0.75}+(\text { final body weight })^{0.75}\right) / 2$.

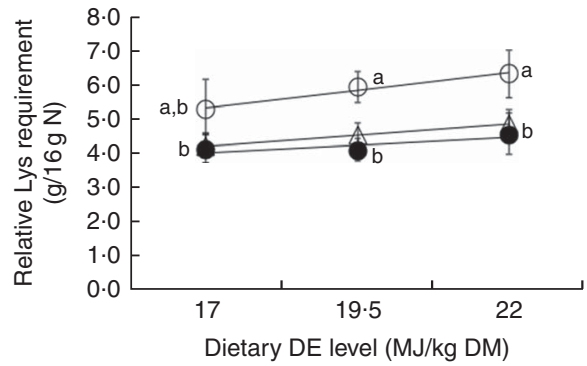

Fig. 5. Relative lysine (Lys) requirement estimates (g Lys/16 g nitrogen; mean and $95 \%$ credible interval of the posterior parameters) for maximum nitrogen gain, plotted against dietary digestible energy (DE) levels (17, 19.5 and $22 \mathrm{MJ}$ $\mathrm{DE} / \mathrm{kg} \mathrm{DM}$ ) and modelled with a linear regression for three dietary digestible protein (DP) levels: $280 \mathrm{~g}$ DP/kg DM (low protein (LP), O), $\quad Y=1.81$ (SE 0.69) +0.21 (SE 0.04) X ( $\left.n 3, r^{2} 0.97, P=0.11\right) ; 440 \mathrm{~g} \mathrm{DP} / \mathrm{kg} \mathrm{DM}$ (medium protein (MP), ๑), $Y=2.56$ (SE 1.17) +0.09 (SE 0.06) $X\left(n 3, r^{2} 0.68, P=0.38\right)$; and $600 \mathrm{~g} \mathrm{DP} / \mathrm{kg} \mathrm{DM}$ (high protein (HP), $\Delta$ ) $Y=2.00$ (SE 0.05 ) +0.13 (SE 0.00) $X$ ( $n 3$, $\left.r^{2} 1.00, P=0.01\right)$. No significant differences were observed between slopes of the three regressions $(P>0.05)$. Each data point represents estimates calculated with nine aquarium of fifty initial fish (rainbow trout of initial body weight $0.85 \mathrm{~g} /$ fish reared at $11.6^{\circ} \mathrm{C}$ for a 24 or a 30 -d feeding period for MP (trial 2) or LP and HP (trial 1) diets, respectively). ${ }^{a, b}$ Mean values with unlike letters of the requirement estimates are significantly different $(0 \notin 95 \% \mathrm{Cl})$.

and the VFI in a series of diets where Lys levels were targeted to go from 'deeply deficient' to 'large excess' (10-150\% according to the National Research Council ${ }^{(8)}$ recommendations for rainbow trout). The DE level varied from adequate content $(17 \mathrm{MJ} / \mathrm{kg}$ dry diet) to excess $(22 \mathrm{MJ} / \mathrm{kg})^{(8)}$, whereas the DP content was considered sub-optimal (LP diets, $280 \mathrm{~g} \mathrm{DP} / \mathrm{kg} \mathrm{DM}$ ), optimal (MP diets, $440 \mathrm{~g}$ DP/kg DM) or supra-optimal (HP diets, $600 \mathrm{~g} / \mathrm{kg} \mathrm{DM}$ ) for rainbow trout juveniles ${ }^{(25,28)}$. Two trials were conducted to test all experimental diets. To allow the comparison of our results between trials, great care was taken to ensure similar experimental conditions, notably in terms of animal origin, fry initial weight, water temperature, stocking density, nutritional history and experimental conditions.

When compared with the growth performance reported by Austreng et al. ${ }^{(38)}$ for the same temperature and fish sizes, optimal growth was recorded for fry fed diets with optimal and supra-optimal Lys levels. This indicates that the use of crystalline AA ( $46 \%$ of dietary $\mathrm{CP}$ ) did not affect growth performance in the present study, as previously reported ${ }^{(9,21)}$. When Lys was adequate or in excess of the requirement, TGC were similar for fish fed MP and HP diets and higher for fish fed MP and HP diets than for fish fed LP diets. This indicates that the value of $440 \mathrm{~g} \mathrm{DP} / \mathrm{kg}$ dry diet met the protein requirement for maximum growth of rainbow trout juveniles.

In the present experiment, the relative Lys requirement calculated from $\mathrm{N}$ gain data varied widely between 13.3 and $26.5 \mathrm{~g} / \mathrm{kg} \mathrm{DM}$, and was significantly increased with the dietary DP level (Table 4). Bodin et al. ${ }^{(9)}$ also reported the positive effect of DP content in rainbow trout fry fed on diets containing 310 or $469 \mathrm{~g} \mathrm{DP} / \mathrm{kg}$ dry diet and varied Lys contents from deficient to large excess $(2-70 \mathrm{~g} / \mathrm{kg} \mathrm{DM})$. In their study, the relative Lys requirements determined with BLM for protein gain were of 16.2 and $22.3 \mathrm{~g} / \mathrm{kg} \mathrm{DM}$ for 310 and $469 \mathrm{~g} \mathrm{DP} / \mathrm{kg} \mathrm{DM}$, respectively. This confirms the importance of this dietary factor on the relative Lys requirement. On the other side, although the relative Lys requirements increased linearly with the dietary DE level in fish fed HP diets $(P<0.05)$, this increase was limited (16\%) compared with the protein effect (69\%) and this increase was not significant in LP and MP diets (Fig. 3). Interestingly, no significant interaction effect between DP and DE levels was observed (Fig. 3). The reduced dietary DE levels tested for each protein concentration ( $n$ 3) possibly limited our ability to detect significant DE effect in LP and MP diets or differences of slopes between regression lines because of the low statistical power. However, the small differences of relative requirement observed in both trials in fish fed varying DE levels may also be not meaningful. Moreover, the relative Lys requirement estimates for $\mathrm{N}$ gain were not significantly different for a same $\mathrm{DE}$ density (Table 4). This lack of DE effect is in accordance with Encarnaçao et al. ${ }^{(10)}$ who showed no significant effect of dietary DE level on the relative Lys requirement for maximum weight gain of rainbow trout weighing about $150 \mathrm{~g}$. To conclude, further research is required in order to assess the specific dietary DE level influence on the relative Lys requirement estimate and its possible interaction effect with DP concentration. However, even 
(a)

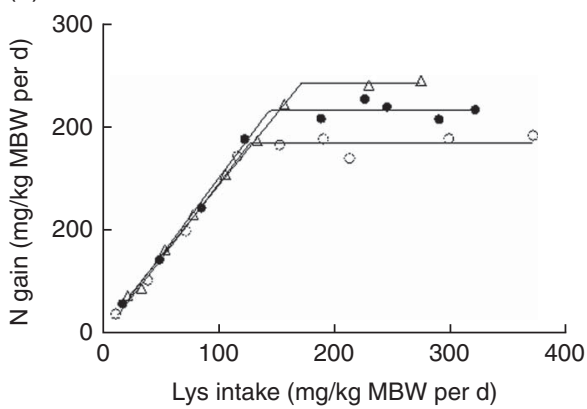

(b)

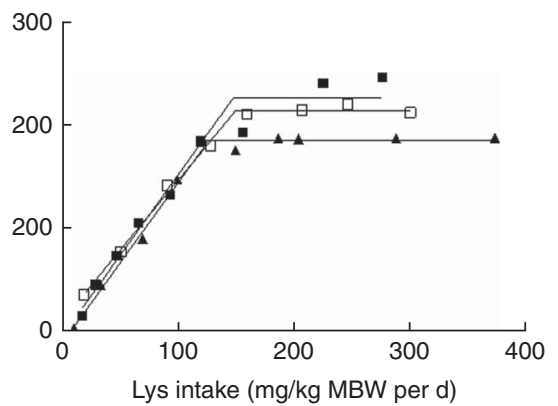

(c)

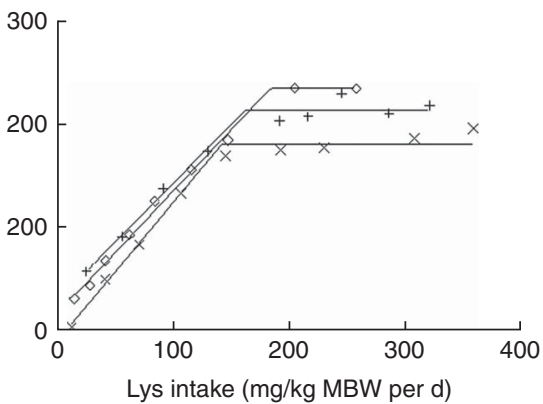

Fig. 6. Absolute lysine (Lys) requirement ( $\mathrm{mg} / \mathrm{kg}$ metabolic body weight (MBW) per d) for maximum nitrogen gain estimated with a broken-line model for three dietary digestible protein (DP) levels (low protein (LP), medium protein (MP) and high protein (HP) containing 280,440 and $600 \mathrm{~g}$ DP/kg DM, respectively) and three dietary digestible energy (DE) levels (low energy (LE), medium energy (ME) and high energy (HE) containing 17, 19.5 and 22 MJ DE/kg DM, respectively). (a) O, LPLE; , MPLE; $\triangle$, HPLE; (b) $\mathbf{\Delta}$, LPME; $\square$, MPME; $\square$, HPME; (c) $\times$, LPHE; + , MPHE; $\diamond$, HPHE. Each data point represents the result of one aquarium with fifty initial fish (rainbow trout of initial body weight $0.85 \mathrm{~g} /$ fish reared at $11.6^{\circ} \mathrm{C}$ for a 24 or a $30-\mathrm{d}$ feeding period for MP (trial 2 ) or LP and HP (trial 1 ) diets, respectively). Parameters of the model are shown in Table $5 . \mathrm{MBW}=\left((\text { initial body weight })^{0.75}+(\text { final body weight })^{0.75}\right) / 2$.

Table 5. Parameters estimated by fitting the experimental data to a broken-line regression at each protein and energy levels for the response criteria of nitrogen gain ( $\mathrm{mg} / \mathrm{kg}$ metabolic body weight $(\mathrm{MBW})$ per $\mathrm{d}$ ) and nitrogen retention efficiency (NRE; $100 \times($ nitrogen gain/nitrogen intake); \%)*

\begin{tabular}{|c|c|c|c|c|c|c|}
\hline \multirow[b]{2}{*}{ Lys requirement in terms of } & \multirow[b]{2}{*}{ Criteria } & \multirow[b]{2}{*}{ Diets } & \multicolumn{4}{|c|}{ Broken-line model parameters } \\
\hline & & & $P$ & $U$ & $R$ & $x$-intercept \\
\hline \multirow[t]{18}{*}{ Lys intake (mg/kg MBW per d) } & \multirow[t]{9}{*}{$\mathrm{N}$ gain } & LPLE & $183 \cdot 87^{\mathrm{C}}$ & $1.48^{\mathrm{a}, \mathrm{b}}$ & $126 \cdot 49^{c}$ & $0.96^{\mathrm{a}, \mathrm{b}}$ \\
\hline & & LPME & $185 \cdot 28^{c}$ & $1 \cdot 55^{\mathrm{a}}$ & $127 \cdot 51^{c}$ & $7 \cdot 41^{\mathrm{a}}$ \\
\hline & & LPHE & $182 \cdot 60^{\mathrm{C}}$ & $1 \cdot 31^{\mathrm{a}, \mathrm{b}}$ & $147 \cdot 29^{b, c}$ & $6 \cdot 49^{a, b}$ \\
\hline & & MPLE & $215 \cdot 52^{b}$ & $1 \cdot 51^{\mathrm{a}, \mathrm{b}}$ & $143 \cdot 70^{c}$ & $-0.03^{a, b}$ \\
\hline & & MPME & $214 \cdot 34^{b}$ & $1 \cdot 36^{\mathrm{a}, \mathrm{b}}$ & $150 \cdot 83^{b, c}$ & $-7 \cdot 91^{a, b}$ \\
\hline & & MPHE & $213.88^{b}$ & $1 \cdot 15^{\mathrm{a}, \mathrm{b}}$ & $163 \cdot 04^{a, b, c}$ & $-26 \cdot 21^{\mathrm{b}}$ \\
\hline & & HPLE & $242 \cdot 27^{\mathrm{a}}$ & $1 \cdot 39^{a, b}$ & $171.46^{\mathrm{a}, \mathrm{b}}$ & $-3 \cdot 00^{a, b}$ \\
\hline & & HPME & $238 \cdot 84^{a, b}$ & $1 \cdot 39^{a, b}$ & $171.96^{a, b, c}$ & $-4.06^{a, b}$ \\
\hline & & HPHE & $234.90^{a}$ & $1 \cdot 19^{b}$ & $184 \cdot 14^{\mathrm{a}}$ & $-13 \cdot 25^{\mathrm{b}}$ \\
\hline & \multirow[t]{9}{*}{ NRE } & LPLE & $40.63^{a}$ & $0.33^{a, b}$ & $117 \cdot 67^{\mathrm{b}, \mathrm{c}}$ & $-16 \cdot 03^{a, b}$ \\
\hline & & LPME & $41 \cdot 37^{a}$ & $0.39^{a}$ & $108 \cdot 78^{c}$ & $0.65^{a}$ \\
\hline & & LPHE & $37.50^{\mathrm{a}, \mathrm{b}, \mathrm{c}}$ & $0.32^{a, b}$ & $121.53^{a, b, c}$ & $3.00^{a}$ \\
\hline & & MPLE & $34.57^{\mathrm{b}, \mathrm{c}}$ & $0.25^{a, b, c}$ & $122 \cdot 21^{a, b, c}$ & $-16 \cdot 16^{a, b}$ \\
\hline & & MPME & $36.95^{b}$ & $0.21^{\mathrm{c}}$ & $147 \cdot 58^{a, b, c}$ & $-27 \cdot 48^{\mathrm{a}, \mathrm{b}}$ \\
\hline & & MPHE & $33 \cdot 25^{b, c}$ & $0 \cdot 21^{a, b, c}$ & $135.91^{a, b, c}$ & $-35 \cdot 89^{a, b}$ \\
\hline & & HPLE & $33 \cdot 13^{b, c}$ & $0.17^{c}$ & $162 \cdot 70^{\mathrm{a}}$ & $-36 \cdot 24^{b}$ \\
\hline & & HPME & $31.74^{c}$ & $0 \cdot 30^{a, b, c}$ & $100 \cdot 48^{a, b}$ & $-21 \cdot 72^{\mathrm{a}, \mathrm{b}}$ \\
\hline & & HPHE & $34 \cdot 74^{\mathrm{b}, \mathrm{c}}$ & $0.15^{\mathrm{b}, \mathrm{c}}$ & $175 \cdot 57^{a, b, c}$ & $-72 \cdot 76^{\mathrm{b}}$ \\
\hline
\end{tabular}

LP, low-protein diets (280 g digestible protein (DP)/kg DM); MP, medium-protein diets (440 g DP/kg DM); HP, high-protein diets (600 g DP/kg DM); LE, lowenergy diets (17 MJ digestible energy (DE)/kg DM); ME, medium-energy diets (19.5 MJ DE/kg DM); HE, high-energy diets (22 MJ DE/kg DM); MBW, $\mathrm{MBW}=\left((\text { initial body weight })^{0.75}+(\text { final body weight })^{0.75}\right) / 2 ; P$, plateau value; $U$, slope; $R$, requirement.

a,b,c Values within a column with unlike superscript letters for a same response criterion were significantly different $(0 \notin 95 \% \mathrm{Cl})$.

* For the details of procedures and diets, see Tables 1 and 2 and the 'Methods' section. Values are from one aquarium containing initially fifty fry of $0.85 \mathrm{~g}$ mean initial body weight. Fish were kept at a temperature of $11.6 \pm 0.3^{\circ} \mathrm{C}$

if significant, the DE main effect seems reduced compared with the DP main effect considering the dietary levels used in the present study.

The effect of dietary DP content on the relative Lys requirement $(\mathrm{g} / \mathrm{kg}$ diet $)$ is poorly studied and controversial in fish nutrition. Using similar response criterion and data modelling, Rodehutscord et $a l .{ }^{(14)}$ and Encarnaçao et al. ${ }^{(10)}$ reported similar growth rates and Lys requirement estimates ( $23 \mathrm{~g} / \mathrm{kg}$ dry diet) in rainbow trout fed different dietary $\mathrm{CP}$ contents (337.5 and $400 \mathrm{~g} / \mathrm{kg} \mathrm{DM}$, respectively $)^{(8)}$. By contrast, when analysing Lys requirement estimates through the fish nutrition literature, Hua $^{(11)}$ showed that the dietary protein level has a significant effect on the relative Lys requirement expressed in $\mathrm{g} / \mathrm{kg}$ dry diet. Moreover, as previously mentioned, our team already reported a marked effect of dietary DP content on the relative Lys requirement ${ }^{(9)}$. In the present study, performed under similar experimental settings as Bodin et al. ${ }^{(9)}$, a clear positive relationship was established between the relative Lys requirement $(\mathrm{g} / \mathrm{kg} \mathrm{DM})$ and the dietary DP content (Table 4). This shows that the relative Lys requirement expressed on a DM or on as is basis is a positive function of the dietary protein concentration in rainbow trout juvenile.

No impact of the dietary energy sources were observed on the relative Lys requirement of the current study. Indeed, the LPHE diet was the fattiest diet, whereas the LPLE diet was the leanest ( $26 v .4 \%$ DM of cod liver oil). Conversely, the LPLE diet 


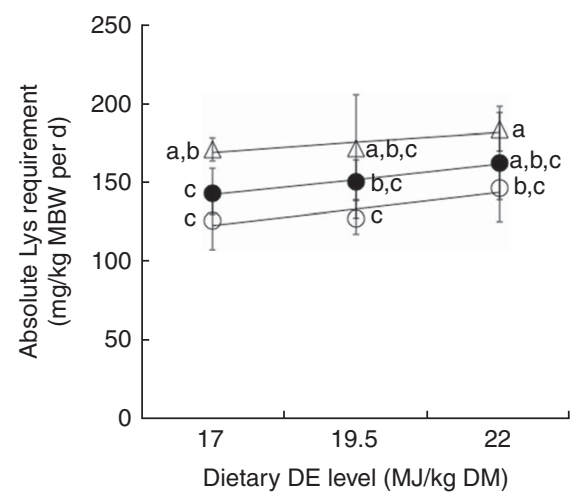

Fig. 7. Absolute lysine (Lys) requirement estimates ( $\mathrm{mg} \mathrm{Lys} / \mathrm{kg}$ metabolic body weight (MBW) per d; mean and $95 \%$ credible interval of the posterior parameters) for maximum nitrogen gain, plotted against dietary digestible energy (DE) levels (17, 19.5 and $22 \mathrm{MJ} D E / \mathrm{kg} \mathrm{DM}$ ) and modelled with a linear regression for three dietary digestible protein (DP) levels $280 \mathrm{~g} \mathrm{DP} / \mathrm{kg} \mathrm{DM}$ (low protein (LP), O), $Y=52.64$ (SE 42.47) + 4.16 (SE 2.17) $X$ ( $n 3, r^{2}, 0.79, P=0.31$ ), $440 \mathrm{~g} \mathrm{DP} / \mathrm{kg}$ DM (medium protein (MP), $\bullet$ ), $Y=77.10$ (SE 11.50) + 3.87 (SE 0.59) $X\left(n 3, r^{2} 0.98, P=0.10\right)$; and $600 \mathrm{~g} \mathrm{DP} / \mathrm{kg} \mathrm{DM}$ (high protein (HP), $\left.\Delta\right)$, $Y=126.40$ (SE 26.44) +2.54 (SE 1.35) $X\left(n 3, r^{2} 0.78, P=0.31\right.$ ). No significant differences were observed between slopes of the three regressions $(P>0.05)$. Each data point represents estimates calculated with nine aquarium of fifty initial fish (rainbow trout of initial body weight $0.85 \mathrm{~g} /$ fish reared at $11.6^{\circ} \mathrm{C}$ for a 24 or a 30-d feeding period for MP (trial 2) or LP and HP (trial 1) diets, respectively). ${ }^{\text {a,b,c }}$ Mean values with unlike letters of the requirement estimates are significantly different $(0 \notin 95 \% \mathrm{Cl})$.

Table 6. Parameters estimated by fitting the linear regression to the experimental data for the response criterion of protein gain in relation to lysine (Lys) intake for the sub-optimal low-protein diets (LP1 to LP4), medium-protein diets (MP1 to MP4) and high-protein diets (HP1 to HP6)*

\begin{tabular}{lccrrr}
\hline & & & & & $\begin{array}{l}\text { Lys required } \\
\text { for } 1 \mathrm{~g} \text { body } \\
\text { protein gain }\end{array}$ \\
\hline Response criterion & Diets & $A$ & \multicolumn{1}{c}{$B$} & $x$-intercept & \\
\hline Lys intake (mg/kg MBW per d) & & & & \\
Protein gain (mg/kg & LPLE & 9.07 & -6.29 & 0.41 & 110.99 \\
MBW per d) & LPME & 9.39 & -51.71 & 5.25 & 107.08 \\
& LPHE & 8.25 & -55.78 & 6.47 & 122.24 \\
& MPLE & 9.35 & 1.89 & -0.50 & 107.53 \\
& MPME & 8.51 & 60.62 & -7.56 & 118.35 \\
& MPHE & 7.33 & 157.26 & -21.81 & 137.00 \\
& HPLE & 8.68 & 25.95 & -3.14 & 115.42 \\
& HPME & 9.68 & -25.40 & 2.40 & 103.75 \\
& HPHE & 7.99 & 72.62 & -9.29 & 125.56
\end{tabular}

LP, low-protein diets (280 g digestible protein (DP)/kg DM); MP, medium-protein diets (440 g DP/kg DM); HP, high-protein diets (600 g DP/kg DM); LE, low-energy diets (17 MJ digestible energy (DE)/kg DM); ME, medium-energy diets (19.5 MJ DE/kg $\mathrm{DM}) ; \mathrm{HE}$, high-energy diets (22MJ DE/kg DM); MBW, MBW=((initial body

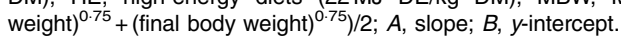

* For the details of procedures and diets, see Tables 1 and 2 and the 'Methods' section. Values are from one aquarium containing initially fifty fry of $0.85 \mathrm{~g}$ mean initial body weight. Fish were kept at a temperature of $11.6 \pm 0.3^{\circ} \mathrm{C}$

was in turn the richest of all diets in digestible carbohydrates (54.6\%). However, the relative Lys requirement estimates for LPLE and LPHE diets were not significantly different, assuming that energy sources had no influence on it. The same conclusion could be applied for the cellulose content as the Lys requirement estimates were not significantly different between HPLE and HPHE diets, which cellulose contents were of 19 and $0 \%$, respectively.
The Lys utilisation efficiency for protein growth (above maintenance) was not affected by the dietary protein level in this study (Table 5). However, Cowey \& Cho ${ }^{(39)}$ assumed that the efficiency of utilisation of the first limiting IAA decreases with increasing dietary protein level because this IAA may not be spared from catabolism by other non-limiting IAA or dispensable AA. On the contrary, more recent studies in accordance with our results showed no impact of the protein level (from $25 \%$ to $65 \% \mathrm{CP}$ in the diet) on the Lys utilisation efficiency in rainbow trout fry ${ }^{(9,20)}$. Moreover, a linear relationship was reported between Lys deposition and Lys intake in the literature on Atlantic salmon dose-response Lys requirement, suggesting a constant Lys utilisation efficiency at marginal Lys intake over different formulations and life stages in Atlantic salmon ${ }^{(40)}$. These observations suggest the existence of a mechanism in salmonids that selectively protect from oxidation the first limiting AA when other AA are supplied in relative excess compared with the first limiting AA (or nutrient) present in the diet. Further studies are needed to explain this mechanism.

The dietary DE concentration did not affect the Lys utilisation efficiency (Table 5). Indeed, when Lys was supplied below the Lys requirement, increasing DE concentration did not lead to improvement of Lys utilisation efficiency for protein growth (above maintenance). Thus, an excess of DE supply in the diet did not lead to any 'sparing effect' of the first limiting IAA (Lys), suggesting no reduction with extra DE of its oxidation in the liver. The absence of 'Lys-sparing' effect with increasing dietary DE density is contradictory to the results reported in trout juveniles by Encarnaçao et $a l^{(10)}$. These authors reported a significant increase of Lys utilisation efficiency (Lys gain/Lys intake) when increasing DE from 16 to $20 \mathrm{MJ} / \mathrm{kg}$ in the diet. However, this increase was relatively small (maximum 5\%) and was observed with Lys gain as response criterion. Lys gain was not measured in the present study, precluding direct comparison. In addition, the dietary DE range studied here was from 17 to $22 \mathrm{MJ} / \mathrm{kg}$, which is equal to or higher than the trout requirement, whereas the dietary $\mathrm{DE}$ of $16 \mathrm{MJ} / \mathrm{kg}$ did not address the requirement in the study of Encarnaçao et $a l^{(10)}$. The different dietary DE levels or the different response criterion could explain the discrepancy between our study and the one published by Encarnaçao et al. ${ }^{(10)}$.

As for $\mathrm{N}$ gain, maximum NRE was related to dietary DP level (Table 5). Indeed, when Lys was provided in adequate or excess amount of the experimentally determined Lys requirement, the DP level had a marked effect on $\mathrm{N}$ gain (or NRE), which were higher (or lower) in fish fed the MP or HP diets, than in those fed the LP diets. The reduced NRE with higher dietary DP level is undoubtedly due to the catabolysis of the excess amount of AA (compared with the first limiting AA), leading to a decrease of their utilisation efficiencies. The catalytic activity of enzymes involved in AA oxidation has been reported to increase with increasing dietary DP content. Indeed, in the study of Kim et al. ${ }^{(41)}$, a higher oxidation rate of dietary glutamine and phenylalanine was observed when trout were fed with $35 \%$ dietary protein in comparison to $10 \%$ dietary protein. Inversely, a lack of control by dietary protein level on AA oxidation had been reported as well ${ }^{(42)}$. Clearly, further studies are needed on this aspect. 

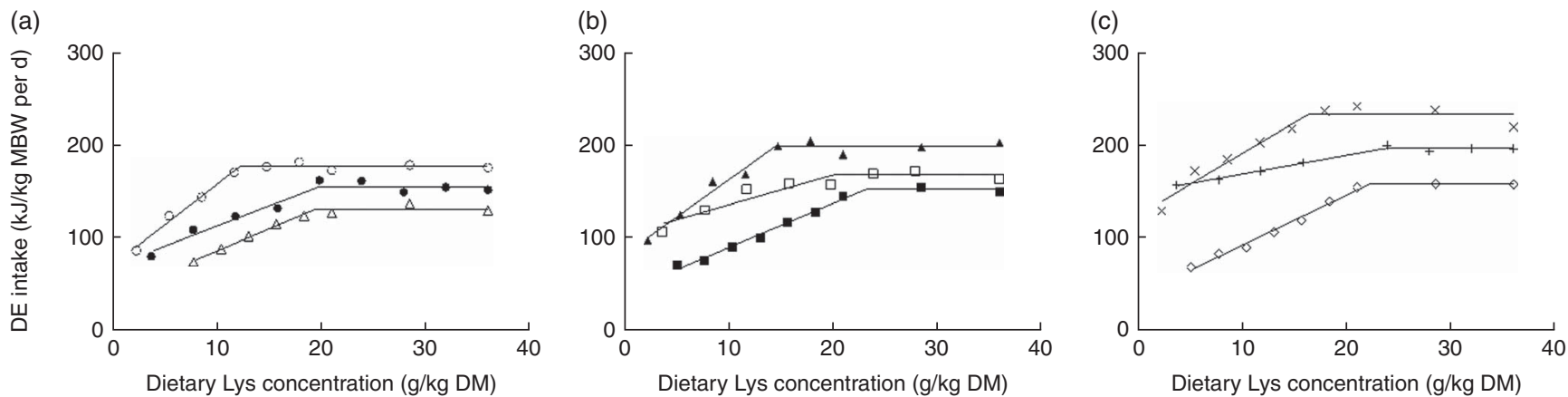

Fig. 8. Digestible energy intake (kJ/kg metabolic body weight (MBW) per d) plotted against dietary lysine concentration ( $\mathrm{g} / \mathrm{kg} \mathrm{DM}$ ) and modelled with the broken-line model for three dietary digestible protein (DP) levels (low protein (LP), medium protein (MP) and high protein (HP) containing 280,440 and $600 \mathrm{~g} \mathrm{DP} / \mathrm{kg} \mathrm{DM}$, respectively) and three dietary digestible energy (DE) levels (low energy (LE), medium energy (ME) and high energy (HE) containing $17,19.5$ and $22 \mathrm{MJ} D E / \mathrm{kg}$ DM, respectively). (a) O, LPLE; $\bullet$, MPLE; $\triangle$, HPLE; (b) $\mathbf{\Delta}$, LPME; $\square$, MPME; $\boldsymbol{\square}$, HPME; (c) $\times$, LPHE; + , MPHE; $\diamond$, HPHE. Each data point represents the result of one aquarium with fifty initial fish (rainbow trout of initial body weight $0.85 \mathrm{~g} / \mathrm{fish}$ reared at $11.6^{\circ} \mathrm{C}$ for a 24 or a 30 -d feeding period for MP (trial 2) or LP and HP (trial 1 ) diets, respectively). Parameters of the model are shown in Table $4 . \mathrm{MBW}=\left((\text { initial body weight })^{0.75}+(\text { final body weight })^{0.75}\right) / 2$.

Table 7. Heat production (digestible energy intake - branchial and urinary loss - gross energy gain) of rainbow trout fry fed eighty-one diets containing three digestible protein (DP) levels and three digestible energy (DE) levels supplemented with nine graded levels of L-lysine (Lys). $\mathrm{HCl}$ for 24 (MP diets) or 30 (LP and HP diets) feeding days*

\begin{tabular}{|c|c|c|c|c|c|c|c|c|c|}
\hline \multicolumn{10}{|c|}{ Dietary Lys concentration (g/kg DM) } \\
\hline LP & $2 \cdot 26$ & $5 \cdot 38$ & 8.51 & 11.63 & $14 \cdot 75$ & $17 \cdot 88$ & 21.00 & $28 \cdot 50$ & $36 \cdot 00$ \\
\hline $\mathrm{HP}$ & $5 \cdot 07$ & $7 \cdot 73$ & $10 \cdot 38$ & $13 \cdot 04$ & $15 \cdot 69$ & $18 \cdot 35$ & 21.00 & $28 \cdot 50$ & $36 \cdot 00$ \\
\hline \multicolumn{10}{|c|}{ Heat production (kJ/kg MBW per d) } \\
\hline LPHE & 104.58 & 123.94 & $116 \cdot 50$ & $120 \cdot 88$ & $124 \cdot 65$ & $145 \cdot 32$ & $149 \cdot 58$ & 145.69 & $126 \cdot 24$ \\
\hline MPLE & 51.97 & 65.89 & 67.40 & $67 \cdot 21$ & $92 \cdot 39$ & $89 \cdot 23$ & $78 \cdot 25$ & $84 \cdot 75$ & 81.52 \\
\hline MPME & $72 \cdot 72$ & $79 \cdot 37$ & $85 \cdot 80$ & $82 \cdot 18$ & $72 \cdot 84$ & $85 \cdot 33$ & 86.29 & $80 \cdot 16$ & $79 \cdot 75$ \\
\hline MPHE & $106 \cdot 27$ & $102 \cdot 20$ & $96 \cdot 13$ & 92.54 & $122 \cdot 38$ & $107 \cdot 50$ & $101 \cdot 65$ & $109 \cdot 81$ & $105 \cdot 28$ \\
\hline HPLE & 52.91 & $47 \cdot 47$ & 51.04 & 53.37 & $55 \cdot 14$ & $58 \cdot 30$ & 57.68 & $63 \cdot 25$ & $57 \cdot 64$ \\
\hline HPME & 53.42 & 43.95 & $55 \cdot 15$ & $51 \cdot 22$ & $62 \cdot 21$ & $58 \cdot 86$ & 71.53 & 73.42 & 67.51 \\
\hline
\end{tabular}

No effect of dietary DE on N gain or NRE was observed in any of the DP levels tested when the Lys amount was equal or above the requirement (Table 5). By contrast, increasing energy-containing nutrients in the ration has been reported to reduce AA catabolism and increase NRE in fish species including salmonids ${ }^{(18,43-45)}$. However, the extra DE provided as lipid has been reported to have no impact on $\mathrm{N}$ utilisation efficiency in rainbow trout ${ }^{(46)}$.

In the present study, the effect of DP content on VFI can be viewed in two different ways. The first view is that VFI gradually decreased with increasing DP content, except in Lys most deficient diets (online Supplementary Tables S3 and S4). In humans, the protein content of food is a strong determinant of short-term satiety and how much food is eaten ${ }^{(47-50)}$. Protein is a more satiating nutrient than carbohydrates and fat ${ }^{(51)}$. In fish, no clear effect of protein on satiation has been demonstrated. In the rainbow trout literature, the VFI was observed to decrease $\mathrm{e}^{(9,18,20,52)}$ or to remain constant ${ }^{(17,53)}$ with increasing dietary protein content. The second view is that VFI gradually increased with decreasing DP level, except in Lys most deficient diets, indicating a specific appetite for protein. Literature data indicate that numerous animal species, including humans and fish, have a separate protein appetite ${ }^{(48,54)}$. Furthermore, when faced with unbalanced diets, humans seem to prioritise the absolute intake of a target level of protein at the expense of the regulation of carbohydrates and lipids intake ${ }^{(50,55)}$. This socalled 'protein leverage' effect has been demonstrated in a variety of species, including non-human primates, pigs, rodents, birds, insects and a salmonid fish, the European whitefish (Coregonus lavaretus $^{(54,56)}$ : when the dietary level of protein is lowered, total energy intake is increased in order to maintain a constant absolute protein intake. In the present study, whereas DEI effectively increased with decreasing DP content, the absolute protein intake was not constant across diets, for adequate Lys contents; in fact, DNI was inferior in the LP diets compared with MP and HP diets. This observation could be 
related to gut volumetric constraints or lead to losses of body cell mass, muscle function and immune response ${ }^{(57)}$. Another explanation could be that trout adopted a 'rule of compromise' between infra-optimal protein intake and postingestive regulation of an excess of non-protein energy, in particular of digestible carbohydrates ${ }^{(54,56)}$. Further studies are needed in order to better understand the effect of DP content on VFI in fish.

Unlike the protein content, the dietary DE level did not significantly influence the VFI (Table 4). Moreover, here, the DEI was related to both dietary DE and DP concentrations, increasing with DE level, and decreasing with DP content, except for Lys-deficient diets (Table 4). These findings contradict the hypothesis that dietary DE concentration would determine the level of DM feed intake ${ }^{(13-16)}$. They also contradict other authors who assumed that fish seem to adjust feed intake to maintain energy intake constant ${ }^{(58,59)}$.

For Saravanan et al. ${ }^{(17)}$, fish eat to meet a constant heat production, because the amount of $\mathrm{VO}_{2}$ theoretically parallels the amount of heat production by aerobic metabolism ${ }^{(60)}$. The degree of nutrient oxidation would generate satiety. However, when heat production was estimated in this current study, values were not constant across diets (Table 7). They decreased with the increasing dietary DP level for a same energy level. Interestingly, the same tendency was observed with the DP content in the study of Saravanan et $a l .{ }^{(18)}$. The contradiction between the two studies of Saravanan et al. ${ }^{(17,18)}$ where diets were produced with similar raw material suggests that another factor may control VFI.

Another theory for the control of VFI in fish is its regulation by diet-induced differences in $\mathrm{VO}_{2}^{(18)}$. The satiating power of a nutrient has been proposed to be determined by its degree of hepatic oxidative metabolism, as reported in the hepatic oxidation metabolism in mammals ${ }^{(61)}$. $\mathrm{VO}_{2}$ was not recorded in the present trials. However, oxygen consumption is directly related to heat production ${ }^{(60)}$ and the latter was observed to decrease with the increasing dietary DP level in our study. Therefore, $\mathrm{VO}_{2}$ increased with increasing VFI, as observed in the study of Saravanan et al. ${ }^{(18)}$

Energy sources did not seem to affect VFI in the present study. As mentioned above, the LPHE diet contained the most oil and the LPLE diet the most digestible carbohydrates. No significant differences were observed between the VFI of fry fed these two diets in the case of optimal and supra-optimal Lys levels (Table 4). Thus, these findings do not support the lipostatic or the glucostatic theories that propose respectively a regulation of VFI by the body fat content ${ }^{(62,63)}$ or by the blood glucose ${ }^{(64,65)}$. On the contrary, these current results were in accordance with studies contradicting these two theories ${ }^{(18,19,66,67)}$.

In fish, relative IAA requirements may be expressed in three different ways: as a percentage of diet (\% or $\mathrm{g} / \mathrm{kg}$ DM diet), as a proportion of diet protein content $(\mathrm{g} / 100 \mathrm{~g}$ protein or $\mathrm{g} / 16 \mathrm{~g} \mathrm{~N})$ or per unit of diet DE $(\mathrm{g} / \mathrm{MJ} \mathrm{DE})$. The first way implies that the diet composition does not influence the IAA requirement for body weight gain, whereas the second one suggests that dietary protein content has an impact. Expressing the IAA requirement per unit of diet DE reflects the assumption that the dietary DE content determines the level of DM feed intake ${ }^{(13-16)}$. In the current study, VFI was not influenced by the diet DE content.
Moreover, in accordance with a previous study ${ }^{(10)}$, the dietary DE content did not seem to affect greatly the relative Lys requirement ( $\mathrm{g} / \mathrm{kg} \mathrm{DM})$, even if this result has to be confirmed. This suggests that expressing IAA requirements in relation to diet DE content is not adequate. By contrast, the diet DP deeply impacted the relative Lys requirement expressed in $\mathrm{g} / \mathrm{kg}$ dry diet in the present study. Therefore, expressing the requirement as a proportion of dietary protein is assumed to be a preferable option than as dietary content. This view is confirmed by the study of Hua ${ }^{(11)}$, where a non-linear mixed model analysis was applied on forty-eight dose-response studies on Lys requirement in fish. The results suggested that expressing Lys requirement as a percentage of dietary protein provides a better goodness of the fit to the modelling data than expressing requirement as a fixed concentration of diet or as a ratio to DE, irrespective of the model choice. In this current study, the relative requirements in $\mathrm{g} / 16 \mathrm{~g} \mathrm{~N}$ estimated with the BLM were similar between MP and HP diets (4.1-4.5 and 4.2-4.8 g Lys/ $16 \mathrm{~g} \mathrm{~N}$, for MP and HP diets respectively). Those estimated in LP diets $(5 \cdot 3-6 \cdot 3 \mathrm{~g} / 16 \mathrm{~g} \mathrm{~N})$ were significantly higher than the other two (except for LPLE diet). The same tendency was reported in chicken, where AA requirement expressed as a percentage of the dietary protein decreased as the protein level increased ${ }^{(68)}$. Moreover, a decrease in the relative Lys requirement for protein growth $(5.4$ and $4.9 \mathrm{~g} / 100 \mathrm{~g}$ protein) was observed with increasing dietary protein content (310 and $469 \mathrm{~g} \mathrm{DP} / \mathrm{kg}$ dry diet, respectively) in rainbow trout fry ${ }^{(9)}$. The lack of dietary protein content in protein-deficient diets may cause the higher relative IAA requirement expressed as a percentage of total dietary protein. Moreover, the relative Lys requirement expressed in this way seemed similar when the protein requirement was met, supporting this last hypothesis. However, only two dietary DP levels were taken into account. More studies are needed to confirm this assumption.

In summary, the present study showed that: the relative Lys requirement of rainbow trout for $\mathrm{N}$ gain increased significantly with increasing dietary DP content for a same DE level, from 13.3 to $22.9 \mathrm{~g}$ Lys/kg DM (LE), from 14.9 to $24.6 \mathrm{~g}$ Lys $/ \mathrm{kg}$ DM (ME) and from 15.7 to $26.5 \mathrm{~g}$ Lys/kg DM (HE); the relative Lys requirement expressed as a proportion of dietary protein was negatively related to the dietary DP level until the dietary DP level met the requirement; the absolute Lys requirement was also affected by dietary DP content but not by DE content; the Lys utilisation efficiency for protein growth above maintenance was constant across DP and DE contents, leading to no 'Lys-sparing' effect of excess dietary DE supply or to no negative effect of excess or deficient DP supply; finally, the VFI of trout fry increased with decreasing dietary DP level, regardless of DE level.

\section{Acknowledgements}

The authors are very grateful to the Support en Méthodologie et Calcul Statistique of the Université catholique de Louvain, and in particular to Vincent Bremhorst, for his assistance with statistical analysis and to the helpful remarks of the anonymous referees.

The present study was supported by funding from the Belgian National Fund for Scientific Research (FNRS-FRFC 
6807370) and by funding from Belspo for the IAP AQUASTRESS (P7/31), from the European Union Seventh Framework Programme (FP7/2007-2013) under grant agreement PIEFGA-2012-332049 for FISHSTRESS project. The funders had no role in the design, analysis or writing of the article.

The authors' contributions are as follows: X. R. designed the study; M. V. L. and G. D. conducted the study and carried out the data collection; M. V. L., Y. L. and X. R. analysed the data; M. V. L., X. R. and Y. L. contributed to the drafting of the paper. None of the authors has any conflicts of interest to declare.

\section{Supplementary material}

For supplementary material/s referred to in this article, please visit https://doi.org/10.1017/S0007114517003300

\section{References}

1. Wilson RP (2002) Protein and amino acids. In Fish Nutrition, 3th ed., pp. 144-179 [JE Halver and RW Hardy, editors]. San Diego, CA: Elsevier Science.

2. Gatlin DM, Barrows FT, Brown P, et al. (2007) Expanding the utilization of sustainable plant products in aquafeeds: a review. Aquacult Res 38, 551-579.

3. Dumas A, de Lange CFM, France J, et al. (2007) Quantitative description of body composition and rates of nutrient deposition in rainbow trout (Oncorbynchus mykiss). Aquaculture 273, 165-181.

4. De la Higuera M (2001) Effects of nutritional factors and feed characteristics on feed intake. In Food Intake in Fish, pp. 250-268 [D Houlihan, T Boujard and M Jobling, editors]. Oxford: Blackwell Science Ltd.

5. D'Mello JF (2003) Adverse effects of amino acids. In Amino Acids in Farm Animal Nutrition, 2nd ed., pp. 125-142 [JFP D'Mello, editor]. Wallingford: CAB International Press.

6. Forbes JM (1995) Specific nutrients affecting intake. In Voluntary Food Intake and Diet Selection in Farm Animals, pp. 226-246. Wallingford: CAB International Press.

7. Li P, Mai K, Trushenski J, et al. (2009) New developments in fish amino acid nutrition: towards functional and environmentally oriented aquafeeds. Amino Acids 37, 43-53.

8. National Research Council (2011) Nutrient Requirements of Fish and Shrimp. Washington, DC: National Academies Press.

9. Bodin N, Govaerts B, Abboudi T, et al. (2009) Protein level affects the relative lysine requirement of growing rainbow trout (Oncorbynchus mykiss) fry. Br J Nutr 102, $37-53$.

10. Encarnaçao P, de Lange C, Rodehutscord M, et al. (2004) Diet digestible energy content affects lysine utilization, but not dietary lysine requirements of rainbow trout (Oncorbynchus mykiss) for maximum growth. Aquaculture 235, 569-586.

11. Hua K (2013) Investigating the appropriate mode of expressing lysine requirement of fish through non-linear mixed model analysis and multilevel analysis. Br J Nutr 109, 1013-1021.

12. Mambrini M \& Guillaume J (1999) Nutrition protéique. In Nutrition et alimentation des poissons et des crustacés, 1st ed., pp. 113-146 [J Guillaume, SJ Kaushik, P Bergot, et al., editors]. Paris: Collection du labo au terrain, Editions INRA.

13. Pfeffer E, Al-Sabty H \& Haverkanp R (1992) Studies on lysine requirements of rainbow trout (Oncorbynchus mykiss) fed wheat gluten as only source of dietary protein. J Anim Physiol Anim Nutr 67, 74-82.
14. Rodehutscord M, Becker A, Pack M, et al. (1997) Response of rainbow trout (Oncorbynchus mykiss) to supplements of individual essential amino acids in a semipurified diet, including an estimate of the maintenance requirement for essential amino acids. J Nutr 127, 1166-1175.

15. Rodehutscord M, Jacobs S, Pack M., et al. (1995) Response of rainbow trout (Oncorbynchus mykiss) growing from 50 to $150 \mathrm{~g}$ to supplements of DL-methionine in a semipurified diet containing low or high levels of cysteine. J Nutr $\mathbf{1 2 5}$, 964-969.

16. Rodehutscord M, Borchert F, Gregus Z, et al. (2000) Availability and utilization of free lysine in rainbow trout (Oncorbynchus mykiss): 1. Effect of dietary crude protein level. Aquaculture 187, 163-176.

17. Saravanan S, Schrama JW, Figueiredo-Silva AC, et al. (2012) Constraints on energy intake in fish: the link between diet composition, energy metabolism, and energy intake in rainbow trout. PLOS ONE 7, 1-10.

18. Saravanan S, Geurden I, Figueiredo-Silva AC, et al. (2013) Voluntary feed intake in rainbow trout is regulated by dietinduced differences in oxygen use. J Nutr 143, 781-787.

19. Geurden I, Gondouin E, Rimbach M, et al. (2006) The evaluation of energy intake adjustments and preferences in juvenile rainbow trout fed increasing amounts of lipid. Physiol Behav 88, 325-332.

20. Nang Thu TT, Parkouda C, de Saeger S, et al. (2009) Protein level does not affect lysine utilization efficiency at marginal lysine intake in growing rainbow trout (Oncorbynchus mykiss) fry. Aquaculture 288, 312-320.

21. Rollin X, Mambrini M, Abboudi T, et al. (2003) The optimum dietary indispensable amino acid pattern for growing Atlantic salmon (Salmo salar L.) fry. Br J Nutr 90, 865-876.

22. Wang J, Yun B, Xue M, et al. (2012) Apparent digestibility coefficients of several protein sources, and replacement of fishmeal by porcine meal in diets of Japanese seabass, Lateolabrax japonicus, are affected by dietary protein levels. Aquac Res 43, 117-127.

23. Sugiura SH, Dong FM, Rathbone CK, et al. (1998) Apparent protein digestibility and mineral availabilities in various feed ingredients for salmonid feeds. Aquaculture 159, 177-202.

24. Gaylord TG, Barrows FT \& Rawles SD (2008) Apparent digestibility of gross nutrients from feedstuffs in extruded feeds for rainbow trout, Oncorbynchus mykiss. I World Aquacult Soc 39, 827-834.

25. Satia BP (1974) Quantitative protein requirements of rainbow trout. Prog Fish-Cult 36, 80-85.

26. Wilson RP \& Cowey CB (1985) Amino acid composition of whole body tissue of rainbow trout and Atlantic salmon. Aquaculture 48, 373-376.

27. Jobling M (2001) Feed composition and analysis. In Food Intake in Fish, pp. 1-24 [D Houlihan, $\mathrm{T}$ Boujard and M Jobling, editors]. Oxford: Blackwell Science Ltd.

28. Guillaume J, Kaushik S, Bergot P, et al. (2001) Nutrition and Feeding of Fish and Crustaceans. Chichester: Springer-Praxis Publishing Ltd.

29. National Research Council (1993) Nutrients Requirements of Fish. Washington, DC: National Academies Press.

30. Mambrini M \& Kaushik SJ (1994) Partial replacement of dietary protein nitrogen with dispensable amino acids in diets of Nile tilapia, Oreochromis niloticus. Comp Biochem Physiol 109, 469-477.

31. Association of Official Analytical Chemists (1995) Official Methods of Analysis, 16th ed., vol. 2. Arlington, VA: AOAC International.

32. Robbins KR, Norton HW \& Baker DH (1979) Estimation of nutrient requirements from growth data. J Nutr 109, 1710-1714. 
33. Robbins KR, Saxton AM \& Southern LL (2006) Estimation of nutrient requirements using broken-line regression analysis. J Anim Sci 84, E155-E165.

34. Boldstad WM (2007) Introduction to Bayesian Statistics, 2nd ed. Hoboken, NJ: Wiley.

35. Plummer M (2014) Rjags: Bayesian graphical models using MCMC. $\mathrm{R}$ package version 3-14. http://www//CRAN. R-project.org/package=rjags (accessed September 2015).

36. Geweke J (1992) Evaluating the accuracy of sampling-based approaches to calculating posterior moments. In Proceedings of the Fourth Valencia International Meeting on Bayesian Statistics, pp. 169-194 [JO Berger, JM Bernardo, AP Dawid and AFM Smith, editors]. Oxford: Clarendon Press.

37. Finke MD, DeFouart GR \& Benevenga NJ (1987) Use of a fourparameter logistic model to evaluate the protein quality of mixtures of Mormon cricket meal and corn gluten meal in rats. J Nutr 117, 1740-1750.

38. Austreng E, Storebakken T \& Asgard T (1987) Growth rate estimates for cultured Atlantic salmon and rainbow trout. Aquaculture 60, 157-160.

39. Cowey CB \& Cho CY (1993) Nutritional requirements of fish. Proc Nutr Soc 52, 417-426.

40. Hauler RC \& Carter CG (2001) Lysine deposition responds linearly to marginal lysine intake in Atlantic salmon (Salmo salar) parr. Aquac Res 32, 147-156.

41. Kim K-I, Grimshaw TW, Kayes TB, et al. (1992) Effect of fasting or feeding diets containing different levels of protein or amino acids on the activities of the liver amino acid-degrading enzymes and amino acid oxidation in rainbow trout (Oncorbynchus mykiss). Aquaculture 107, 89-105.

42. Kaushik SJ \& Seiliez I (2010) Protein and amino acid nutrition and metabolism in fish: current knowledge and future needs. Aquacult Res 41, 322-332.

43. Azevedo PA, Leeson S, Cho CY, et al. (2004) Growth and feed utilization of large size rainbow trout (Oncorbynchus mykiss) and Atlantic salmon (Salmo salar) reared in freshwater: diet and species effects, and responses over time. Aquacult Nutr 10, 401-411.

44. Nankervis L, Matthews SJ \& Appleford P (2000) Effect of dietary non-protein energy source on growth, nutrient retention and circulating insulin-like growth factor I and triiodothyronine levels in juvenile barramundi, Lates calcarifer. Aquaculture 191, 323-335.

45. Santhina PJM, Medale F, Corraze G, et al. (1999) Effects of the dietary protein: lipid ratio on growth and nutrient utilization in gilthead seabream (Sparus aurata L.). Aquacult Nutr 5, 147-156.

46. Azevedo PA, Leeson S, Cho CY, et al. (2004) Growth, nitrogen and energy utilization of juveniles from four salmonid species: diet, species and size effect. Aquaculture 234, 393-414.

47. Anderson GH \& Moore SE (2004) Dietary proteins in the regulation of food intake and body weight in humans. $J$ Nutr 134, 974S-979S.

48. Griffioen-Roose S, Mars M, Siebelink E, et al. (2012) Protein status elicits compensatory changes in food intake and food preferences. Am J Clin Nutr 95, 32-38.

49. Raubenheimer D \& Simpson SJ (2016) Nutritional ecology and human health. Annu Rev Nutr 36, 603-626.

50. Simpson SJ \& Raubenheimer D (2005) Obesity: the protein leverage hypothesis. Obes Rev 6, 133-142.
51. Veldhorst M, Smeets AJPG, Soenen S, et al. (2008) Proteininduced satiety: effects and mechanisms of different proteins. Physiol Behav 94, 300-307.

52. Fournier V, Gouillou-Coustans MF, Métailler R, et al. (2002) Protein and arginine requirements for maintenance and nitrogen gain in four teleosts. J Nutr 87, 459-469.

53. Figueiredo-Silva AC, Saravanan S, Schrama JW, et al. (2012) Macronutrient-induced differences in food intake relate with hepatic oxidative metabolism and hypothalamic regulatory neuropeptides in rainbow trout (Oncorbynchus mykiss). Physiol Behav 106, 499-505.

54. Simpson SJ \& Raubenheimer D (2012) The Nature of Nutrition: A Unifying Framework from Animal Adaptation to Human Obesity. Princeton, NJ: Princeton University Press.

55. Gosby AK, Conigrave AD, Lau NS, et al. (2011) Testing protein leverage in lean humans: a randomised controlled experimental study. PLOS ONE 6, e25929.

56. Ruohonen K, Simpson SJ \& Raubenheimer D (2007) A new approach to diet optimisation: a re-analysis using European whitefish (Coregonus lavaretus). Aquaculture 267, 147-156.

57. Castaneda C, Charnley JM, Evans WJ, et al. (1995) Elderly women accommodate to a low-protein diet with losses of body cell mass, muscle function and immune response. $A m J$ Clin Nutr 62, 30-39.

58. Boujard T \& Medale F (1994) Regulation of voluntary feed intake in juvenile rainbow trout fed by hand or by self-feeders with diets containing two different protein/energy ratio. Aquat Living Resour 7, 211-215.

59. Yamamoto T, Sugita T \& Furuita H (2005) Essential amino acid supplementation to fish meal-based diets with low protein to energy ratios improves the protein utilization in juvenile rainbow trout Oncorbynchus mykiss. Aquaculture 246, 379-391.

60. McLean J (1972) On the calculation of heat production from open-circuit calorimetric measurements. Br J Nutr 27, 597-600.

61. Allen MS \& Bradford BJ (2012) Control of food intake by metabolism of fuels: a comparison across species. Proc Nutr Soc 71, 401-409.

62. Kennedy GC (1953) The role of depot fat in the hypothalamic control of food intake in the rat. Proc $R$ Soc Lond B Biol Sci 140, 578-592.

63. Yamamoto T, Shima T, Furuita H, et al. (2002) Influence of dietary fat level and hole-body adiposity on voluntary energy intake by juvenile rainbow trout Oncorbynchus mykiss (Walbaum) under self-feeding conditions. Aquacult Res 33, $715-723$.

64. Mayer J (1953) Glucostatic mechanism of regulation of food intake. N Engl J Med 249, 13-16.

65. Mobbs CV, Isoda F, Makimura $\mathrm{H}$, et al. (2005) Impaired glucose signaling as a cause of obesity and the metabolic syndrome: the glucoadipostatic hypothesis. Physiol Behav 85, 3-23.

66. Gélineau A, Corraze G, Boujard T, et al. (2001) Relation between dietary lipid level and voluntary feed intake, growth, nutrient gain, lipid deposition and hepatic lipogenesis in rainbow trout. Reprod Nutr Dev 41, 487-503.

67. Polakof S, Miguez JM \& Soengas JL (2008) Dietary carbohydrates induce changes in glucosensing capacity and food intake of rainbow trout. Am J Physiol Regul Integr Comp Physiol 295, R478-R489.

68. Almquist HJ (1952) Amino acid requirements of chickens and turkeys - a review. Poult Sci 31, 966-981. 